\title{
name \\ Horizon Scan of Transboundary Concerns Impacting Snow Leopard Landscapes in Asia
}

\author{
Hameeda Sultan ${ }^{1}$, Wajid Rashid ${ }^{1,2}{ }^{\circledR}$, Jianbin Shi ${ }^{1}$, Inam ur Rahim ${ }^{3}$, Mohammad Nafees $^{4}{ }^{\oplus}$, Eve Bohnett ${ }^{5}(\mathbb{C}$, \\ Sajid Rashid ${ }^{1}$, Muhammad Tariq Khan ${ }^{6}\left(\mathbb{D}\right.$, Izaz Ali Shah ${ }^{1}$, Heesup Han ${ }^{7, *(1)}$ and Antonio Ariza-Montes ${ }^{8}$
}

1 School of Environment, Beijing Normal University, Beijing 100875, China; hameeda@mail.bnu.edu.cn (H.S.); wajid@uswat.edu.pk (W.R.); jbshi@bnu.edu.cn (J.S.); 201929180010@mail.bnu.edu.cn (S.R.); izazalishah93@yahoo.com (I.A.S.)

2 Department of Environmental and Conservation Sciences, University of Swat, Mingora Swat 19130, Pakistan

3 Centre for Applied Policy Research in Livestock (CAPRIL), Department of Climate Change and Livestock, University of Veterinary and Animal Sciences, Lahore 54600, Pakistan; inam.rahim@uvas.edu.pk

4 Department of Environmental Sciences, University of Peshawar, Peshawar 25000, Pakistan; nafees@uop.edu.pk

5 Department of Biology, San Diego State University, San Diego, CA 92182, USA; ebohnett@sdsu.edu

6 Department of Science and Environmental Studies, The Education University of Hong Kong, Taipo, New Territories, Hong Kong, China; s1130787@s.eduhk.hk

7 College of Hospitality and Tourism Management, Sejong University, Seoul 05006, Korea

8 Social Matters Research Group, Universidad Loyola Andalucía, C/Escritor Castilla Aguayo, 4, 14004 Córdoba, Spain; ariza@uloyola.es

* Correspondence: heesup@sejong.ac.kr

check for

updates

Citation: Sultan, H.; Rashid, W.; Shi, J.; Rahim, I.u.; Nafees, M.; Bohnett, E.; Rashid, S.; Khan, M.T.; Shah, I.A.; Han, H.; et al. Horizon Scan of Transboundary Concerns Impacting Snow Leopard Landscapes in Asia. Land 2022, 11, 248. https://doi.org/ 10.3390/land11020248

Academic Editors: Bastian Bertzky, Colleen Corrigan and Susan Snyman

Received: 20 December 2021

Accepted: 3 February 2022

Published: 7 February 2022

Publisher's Note: MDPI stays neutral with regard to jurisdictional claims in published maps and institutional affiliations.

Copyright: (C) 2022 by the authors. Licensee MDPI, Basel, Switzerland. This article is an open access article distributed under the terms and conditions of the Creative Commons Attribution (CC BY) license (https:// creativecommons.org/licenses/by/ $4.0 /)$.

\begin{abstract}
The high-altitude region of Asia is prone to natural resource degradation caused by a variety of natural and anthropogenic factors that also threaten the habitat of critical top predator species, the snow leopard (Panthera uncia). The snow leopard's landscape encompasses parts of the twelve Asian countries and is dominated by pastoral societies within arid mountainous terrain. However, no investigation has assessed the vulnerability and pathways towards long-term sustainability on the global snow leopard landscape scale. Thus, the current study reviewed 123 peer-reviewed scientific publications on the existing knowledge, identified gaps, and proposed sustainable mitigation options for the longer term and on larger landscape levels in the range countries. The natural resource degradation in this region is caused by various social, economic, and ecological threats that negatively affect its biodiversity. The factors that make the snow leopard landscapes vulnerable include habitat fragmentation through border fencing, trade corridor infrastructure, non-uniform conservation policies, human-snow leopard conflict, the increasing human population, climatic change, land use and cover changes, and unsustainable tourism. Thus, conservation of the integrated Socio-Ecological System (SES) prevailing in this region requires a multi-pronged approach. This paper proposes solutions and identifies the pathways through which to implement these solutions. The prerequisite to implementing such solutions is the adoption of cross-border collaboration (regional cooperation), the creation of peace parks, readiness to integrate transnational and cross-sectoral conservation policies, a focus on improving livestock management practices, a preparedness to control human population growth, a readiness to mitigate climate change, initiating transboundary landscape-level habitat conservation, adopting environment-friendly trade corridors, and promoting sustainable tourism. Sustainable development in this region encompasses the political, social, economic, and ecological landscapes across the borders.
\end{abstract}

Keywords: collaboration; habitat; innovative solutions; integrated landscape approach; socioecological system; trade corridor; tourism 


\section{Introduction}

High Asia, the high-altitude habitat of the snow leopard (Panthera uncia), covers the mountainous regions of Asia's twelve countries, including Afghanistan, Bhutan, China, India, Kazakhstan, Kyrgyzstan, Mongolia, Nepal, Pakistan, Russia, Tajikistan, and Uzbekistan. The snow leopard habitat mainly comprises the Himalayan mountain ranges: Altai, Tien shan, Kunlun, Pamirs, Karakorum, and Hindukush ranges [1-3] in high Asia (Figure 1). The transboundary landscape occupied by snow leopards covers an area of about 3.0247 million square kilometers [4]. China possesses about $60 \%$ of the global snow leopard landscape, and China shares its border with 10 (the only exception being Uzbekistan) out of the total 12 snow leopard range countries $[1,5]$.

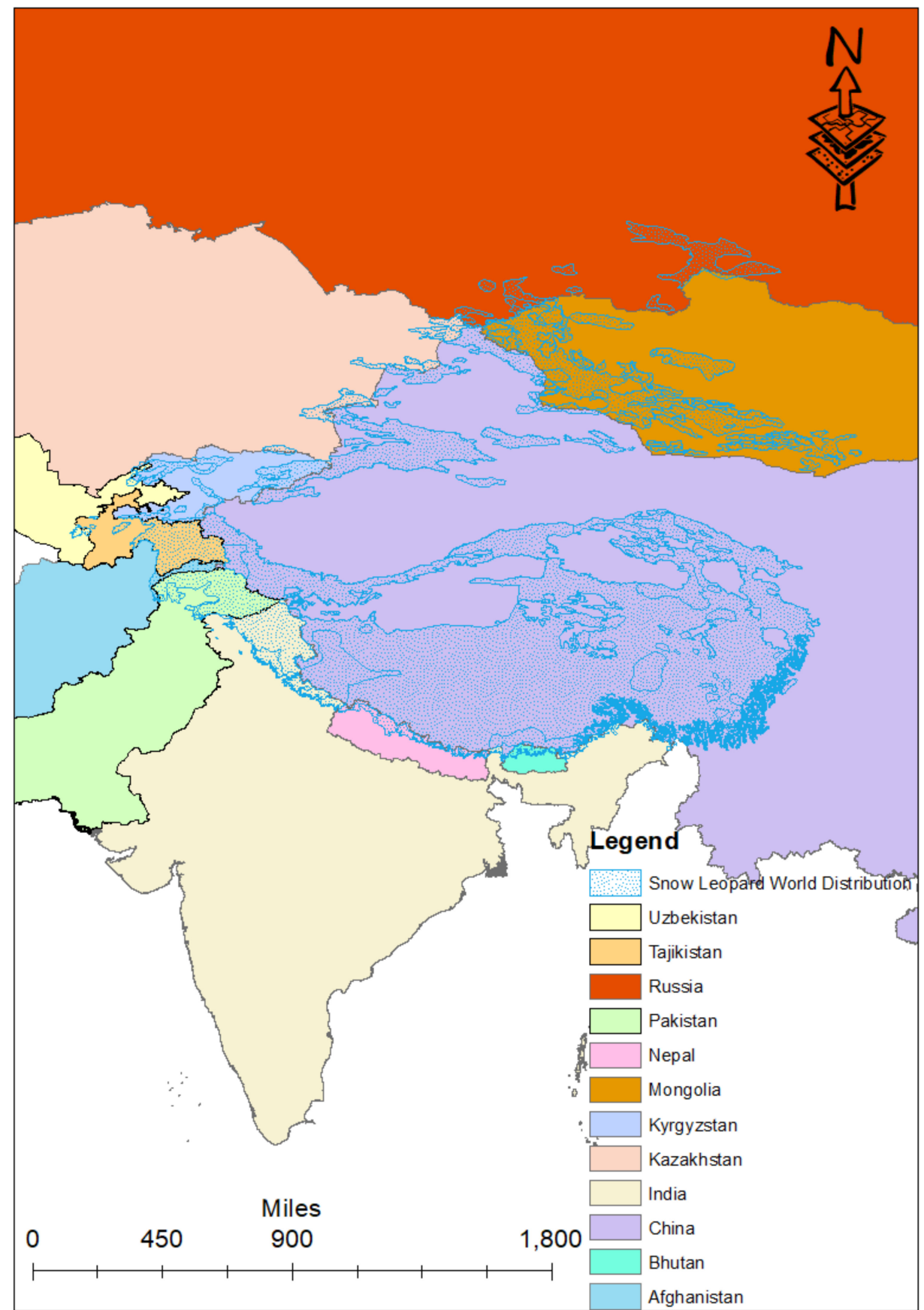

Figure 1. The transboundary snow leopard landscape in the Asian region covering 12 countries. 
The snow leopard is an umbrella species from the high-altitude transboundary Asian regions [6]. It is a threatened carnivore of an elusive and secretive nature. Globally, the population of snow leopards is estimated to be $4500-7500$ animals in the wild [2]. It is one of the least studied big cats and an important threatened species at the global level. This rare big cat inhabits remote and rugged mountain terrains that are difficult to study $[7,8]$. Within the habitat, the snow leopard is adapted to the harsh environment, rough rocky territories, and extremely cold temperatures at higher elevations [9,10]. Snow leopards have low densities across its habitat $[5,8]$. The snow leopard maintains the biological diversity as a top predator [6] and therefore plays a significant role in the continued supply of ecosystem services in this high mountain region [11].

Various political, social, economic, and ecological challenges have placed severe stress on snow leopards in the high-altitude Asian regions and have destabilized and fragmented their natural habitats. The multitude of factors include political boundaries and the associated fencing, climate change, transboundary infrastructure development, encroachment of agriculture and human settlements into the habitats of carnivores and their prey species, human-snow leopard conflict, and illegal trade in snow leopard skin and bones [12-18]. The political fragmentation of the habitat, however, prevents the adoption of an integrated transboundary landscape approach to handle the issue of integrated habitat conservation and can be seen as the overarching phenomenon that has bearing on all the other factors and their mitigation.

The lack of appropriate environmental management in the face of increasing human use of this landscape for human settlements, transboundary infrastructure development, pasturing, cropping, and tourism is leading to the increased vulnerability of the snow leopard $[13,19]$. An impending ecological collapse is also destroying the balance of the prevailing socio-economic and ecological system in the snow leopard habitat [20].

The challenges to mitigating the vulnerabilities of the transboundary snow leopard landscapes include land use and cover changes [21], habitat degradation [22,23], climate change [24,25], human-snow leopard conflict [1,26,27], political inefficiency [16], and border fencing [17]. The conservation policies are only effective if they incorporate ecological and social mechanisms that can positively impact the socio-ecological systems $[28,29]$.

Most of the studies conducted on snow leopard habitats are fragmented and are carried out at the micro- and meso-scale. Additionally, no investigation has assessed the vulnerability and pathways towards long-term sustainability on a larger or regional scale. The current paper, therefore, intends to review the existing knowledge, identify gaps, and propose sustainable mitigation options for the longer term and at a larger landscape level across the aforementioned countries. It will cover the multi-dimensional aspects of vulnerability (Figure 2) and propose solutions in a vast region encompassing all of high Asia's snow leopard range countries. 


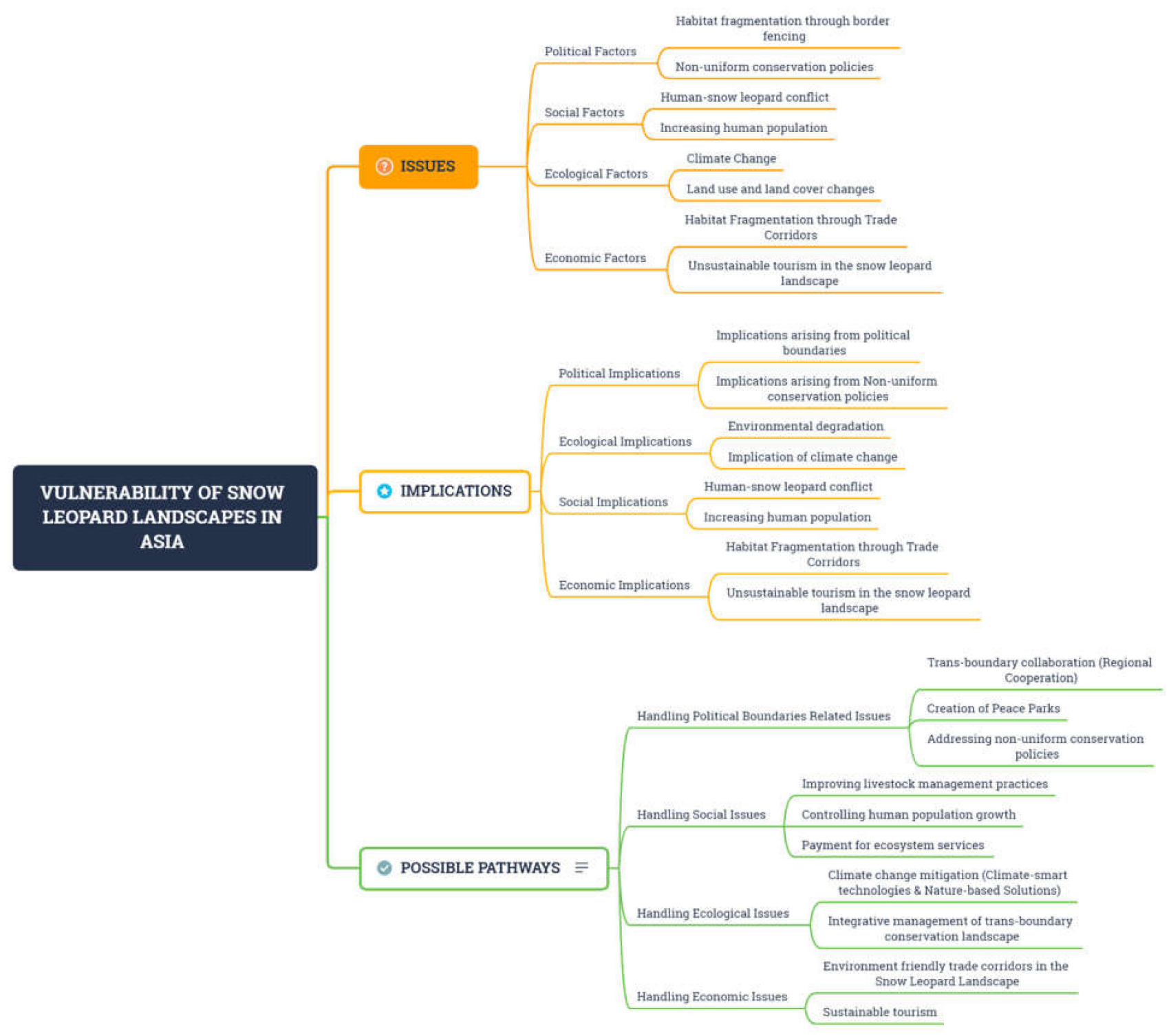

Figure 2. The workflow of the current review, displaying the vulnerability of snow leopard landscapes in the framework of issues, implications, and possible pathways.

\section{Transboundary Vulnerability Factors at the Global Snow Leopard Landscape Level}

During the last few years, increasing attention has focused on assessing wildlife vulnerability at the level of the socio-ecological system [30]. A range of factors are responsible for the increasing vulnerability of socio-ecological systems over the larger snow leopard habitat (Figure 3). The prominent factors enhancing vulnerability in this region include the following.

\subsection{Political Factors}

\subsubsection{Habitat Fragmentation through Border Fencing}

The snow leopard landscape spans international borders and includes some of the world's most disputed borders, including the Line of Control (LOC) between Pakistan and India and between India and China [16,31]. The closure or fencing of the international borders creates many problems for the snow leopards and their prey species [16,32], reducing food, water, and mating potential, thus leading to declining populations [31]. Previous research in the snow leopard landscape revealed that $500 \mathrm{~km}$ of fencing on the border of Pakistan and India resulted in a 60\% decline in the endangered Kashmir Markhor (Capra falconeri falconeri) [33], a crucial wild prey of snow leopards in the boundary region of 
Pakistan and India [2,34]. This closure confines the snow leopards to fragmented habitats that sometimes have scare prey populations, causing the snow leopard to resort to hunting domestic livestock $[24,35]$. Studies have revealed that border closure results in the division of wildlife populations and blocks the migration routes of wild animals [36]. The closure also has a terrible impact on the gene flow in snow leopard populations and is a menace to the survival of this emblematic carnivore species in the long run [37].

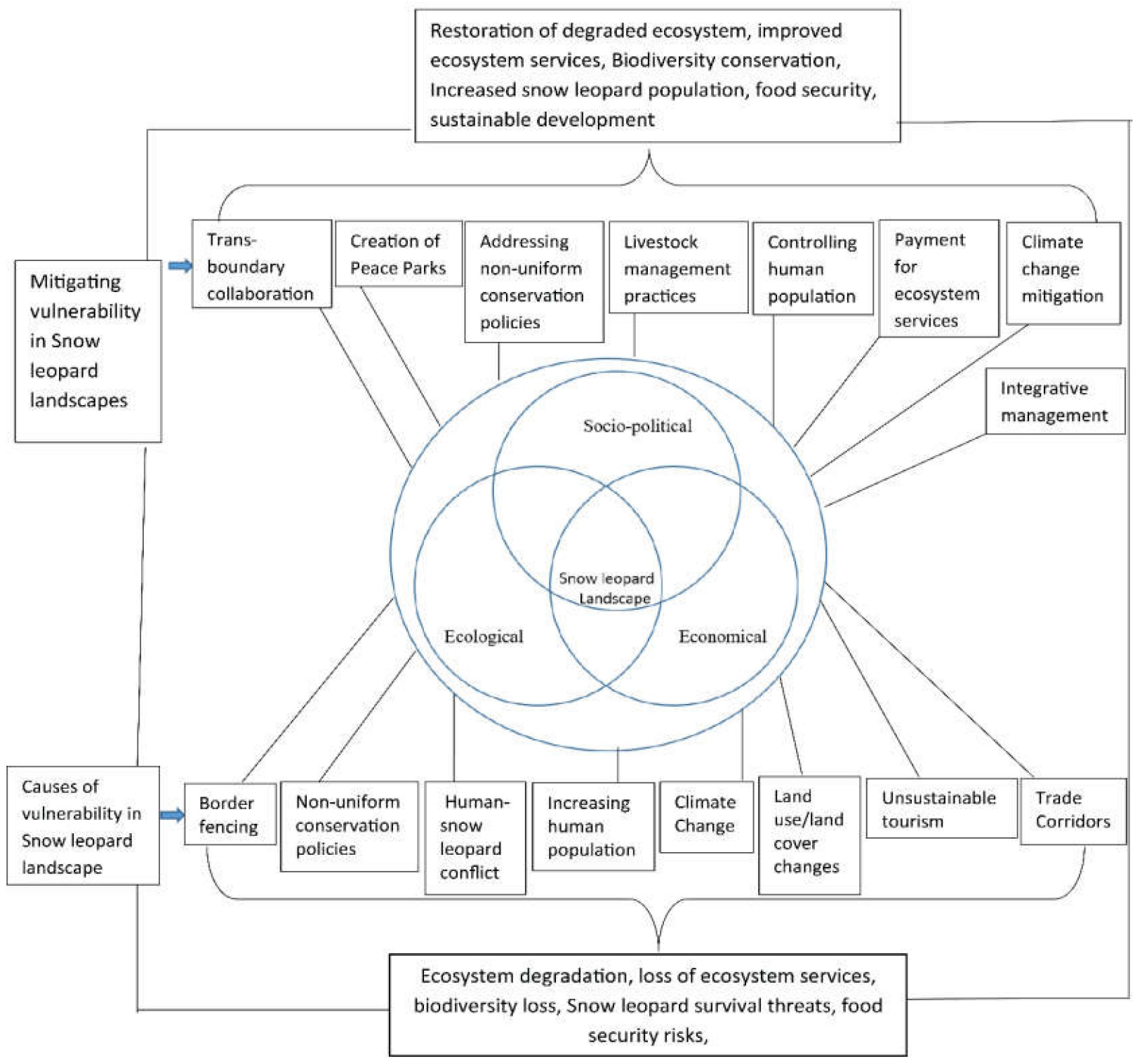

Figure 3. The socio-ecological system of the snow leopard habitat region in the framework of vulnerability and management strategies.

\subsubsection{Non-Uniform Conservation Policies}

The scale of prominent environmental problems or challenges varies from the regional to the global level [38]. Similarly, the global snow leopard landscape is spread over the twelve countries in the high Asian region [1]. Thus, the snow leopard landscapes crisscross the boundaries of different regions [17]. Moreover, the policies of a country are commonly aligned according to the best national interests, while regional or global interests are generally given less priority [39]. 


\subsection{Social Factors}

\subsubsection{Human-Snow Leopard Conflict}

In the highest mountain ranges of Asia, the snow leopard is an apex predator and an opportunistic generalist carnivore, consuming any available prey and killing domestic livestock in large numbers (Table 1) [40-42]. Depredation is the single most important cause of the human-snow leopard conflict $[43,44]$. Since livestock depredation is a threat to livestock owner livelihoods and hence an economic burden [45], these negative perceptions lead to human-snow leopard conflict [46]. The livestock depredation rate depends on the availability of wild prey and the local population of snow leopards, and can be ameliorated by using livestock guarding methods like strong corrals and herding dogs/watchdogs [47]. The snow leopard is known for livestock killings, with mass killings of livestock being reported if corrals are attacked [4,27]. This is the single most prominent reason for the retaliatory killings of snow leopards $[45,48,49]$.

Table 1. The details of livestock type and number predated by snow leopards in different ranges and countries.

\begin{tabular}{|c|c|c|c|c|c|c|}
\hline No. & $\begin{array}{l}\text { Global Snow } \\
\text { Leopard Range }\end{array}$ & Country & $\begin{array}{l}\text { Type of Livestock } \\
\text { Predated by Snow Leopard }\end{array}$ & $\begin{array}{l}\text { No. of Livestock } \\
\text { Depredated }\end{array}$ & Year & Reference \\
\hline 1 & \multirow{4}{*}{ 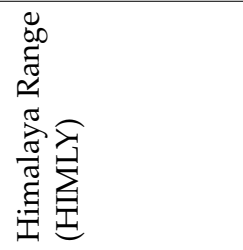 } & Bhutan & Yaks, Horses, Cattle, Sheep, & 32 & 2003-2005 & {$[50]$} \\
\hline 2 & & China & $\begin{array}{l}\text { Yaks, Cattle-Yak hybrid, Cows, } \\
\text { Sheep and Goats }\end{array}$ & 5877 & 2011-2013 & {$[51]$} \\
\hline 3 & & India & Horse, Yaks, Goat, Sheep, others & 112 & 2003 & [52] \\
\hline 4 & & Nepal & $\begin{array}{l}\text { Horses, Yak, Yak-Cow hybrid, } \\
\text { Cows, Goats, Sheep }\end{array}$ & 362 & 2014 & [53] \\
\hline 5 & \multirow{2}{*}{ 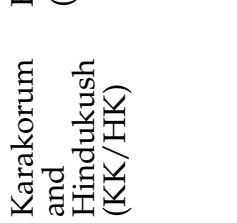 } & Afghanistan & $\begin{array}{l}\text { Yaks, Horses, Cattle, Sheep, } \\
\text { Goats }\end{array}$ & 378 & 2007-2008 & {$[54]$} \\
\hline 6 & & Pakistan & $\begin{array}{l}\text { Yak, Yak-Cow hybrid, Cows, } \\
\text { Goats, Sheep }\end{array}$ & 223 & 2013 & [45] \\
\hline 7 & \multirow{4}{*}{ 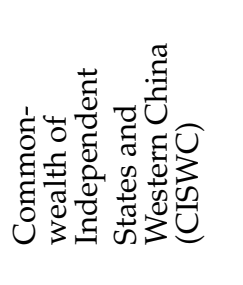 } & Kazakhstan & -None- & 一 & - & - \\
\hline 8 & & Kyrgyzstan & -None- & 一 & - & - \\
\hline 9 & & Tajikistan & -None- & - & - & - \\
\hline 10 & & Uzbekistan & Horses, Sheep, and Goats & 82 & 2004 & {$[55]$} \\
\hline 11 & \multirow{2}{*}{ 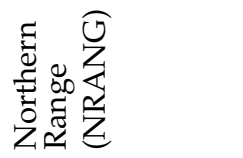 } & Mongolia & Horses, Sheep, Goats & 740 & 2010 & [56] \\
\hline 12 & & Russia & Sheep and Goats & 233 & 2000-2003 & [57] \\
\hline
\end{tabular}

\subsubsection{Increasing Human Population}

Globally, human population density and population growth are challenges for the survival of wild carnivores [58]. The human population is growing at a fast rate in the snow leopard range countries, for example, China's population will increase from 1.37 billion in 2016 to 1.42 billion in 2025 [59]. In India, the human population will grow from current 1.35 billion to 1.47 billion in 2031 [60]. Similarly, Pakistan has a population of 216.6 million with high annual growth rate of $2 \%$ [61]. Moreover, an earlier study revealed that the increasing human population density has negative consequences for biodiversity [62]. The increasing human population and the increasing demands for natural resources are putting pressure on the world's remaining wild habitats and the associated wild animals [63]. 


\subsection{Ecological Factors}

\subsubsection{Climate Change}

One of the major challenges for biodiversity and ecosystems worldwide is climate change $[64,65]$. Snow leopard landscapes span the world's highest mountains, which mostly consist of semi-arid and fragile high mountain ecosystems that are particularly vulnerable to climatic changes [5]. Climate change impacts snow leopard landscapes through increasing temperatures, permafrost degradation, glacier retreat, and loss of surface water [66]. From 1951 to 2012, the global mean surface temperature increased at $0.12{ }^{\circ} \mathrm{C} /$ decade $[67,68]$. However, the mean surface temperature at different locations in the snow leopard landscape exhibits a more pronounced increase from $0.16{ }^{\circ} \mathrm{C} /$ decade to $0.90{ }^{\circ} \mathrm{C} /$ decade (Table 2). Similarly, a temperature increase of $0.20^{\circ} \mathrm{C} /$ decade from 1955 to 2012 was revealed in the Karakorum (Pakistan) snow leopard landscape [69,70]. Previous studies in the snow leopard landscape reveal that climate change profoundly influences the socio-ecological system, and coping with climate change is one of the most urgent issues $[71,72]$.

Table 2. Climate warming rates from the selected sources in the snow leopard landscape (listed from north to south).

\begin{tabular}{|c|c|c|c|}
\hline Location & Period & Warming Rate & Reference \\
\hline Global Mean Surface Temperature & 1951-2012 & $0.12{ }^{\circ} \mathrm{C} /$ decade & $\begin{array}{l}{[67]} \\
{[68]}\end{array}$ \\
\hline Altai Sayan Ecoregion (Russia) & 1976-2008 & $0.58^{\circ} \mathrm{C} /$ decade & {$[73]$} \\
\hline Almaty (Kazakhstan) & 1974-2015 & $0.52{ }^{\circ} \mathrm{C} /$ decade & [74] \\
\hline Naryn (Kyrgyzstan) & $1930-1989$ & $0.32{ }^{\circ} \mathrm{C} /$ decade & [75] \\
\hline Oygaing, (Uzbekistan) & 1961-2016 & $0.25^{\circ} \mathrm{C} /$ decade & [76] \\
\hline Pamir mountains (Tajikistan) & $1979-2018$ & $0.32{ }^{\circ} \mathrm{C} /$ decade & [77] \\
\hline Tibetan Plateau (China) & $1955-1996$ & $0.16^{\circ} \mathrm{C} /$ decade & [78] \\
\hline Dingri, Tibetan Plateau (China) & 1959-2007 & $0.62{ }^{\circ} \mathrm{C} /$ decade & [79] \\
\hline Gilgit (Pakistan) & 1986-2010 & $0.39{ }^{\circ} \mathrm{C} /$ decade & [80] \\
\hline $\begin{array}{l}\text { Hindukush Himalaya region } \\
\text { (Parts of Afghanistan, Pakistan, Tajikistan, China, India, Nepal, } \\
\text { Bhutan) }\end{array}$ & 1951-2014 & $0.20^{\circ} \mathrm{C} /$ decade & [81] \\
\hline Trans-Himalaya Region (Nepal) & 1977-1994 & $0.90^{\circ} \mathrm{C} /$ decade & {$[82]$} \\
\hline
\end{tabular}

\subsubsection{Land Use and Land Cover Changes}

Land use and land cover changes cause increasing vulnerability in the snow leopard landscapes $[65,83,84]$. Previous studies revealed that land use and cover changes like human settlements, overgrazing, mining, road building, and hydrological development projects impacted the snow leopard landscapes $[63,85,86]$. In Bhutan, the total area covered by forest increased markedly compared to other land cover types in three decades (1990 to 2010), representing a rare example of environmental transformation due to climate change affecting the snow leopard landscape [87]. A contrasting situation of land degradation, deforestation, and habitat fragmentation occurred in all other range countries (Table 3) in the snow leopard landscape [88-90]. 
Table 3. Land use/land cover changes (in the snow leopard landscape) in the range countries.

\begin{tabular}{|c|c|c|c|c|c|}
\hline No. & $\begin{array}{l}\text { Global Snow } \\
\text { Leopard Range }\end{array}$ & $\begin{array}{l}\text { Country/ } \\
\text { Location }\end{array}$ & $\begin{array}{l}\text { Type of Land } \\
\text { Use/Landcover Changes }\end{array}$ & Period & Source \\
\hline 1 & 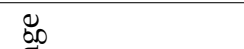 & Bhutan & Increase in forest cover & 1990-2010 & [87] \\
\hline 2 & $\underset{\widetilde{\sigma}}{\tilde{\widetilde{E}}}$ & $\begin{array}{l}\text { Qinghai-Tibet Plateau, } \\
\text { China }\end{array}$ & $\begin{array}{l}\text { Grassland decreased } \\
\text { Unused land increased }\end{array}$ & 1980-2018 & [89] \\
\hline 3 & 胥 & $\begin{array}{l}\text { Central Himalayas, } \\
\text { (India) }\end{array}$ & $\begin{array}{l}\text { Increasing deforestation, } \\
\text { Forest fragmentation }\end{array}$ & 1976-2006 & [91] \\
\hline 4 & 星襾 & Nepal & $\begin{array}{l}\text { Deforestation } \\
\text { Forest degradation }\end{array}$ & 1976-2001 & [92] \\
\hline 5 & $\varepsilon \frac{\frac{5}{2}}{\frac{2}{2}}$ & Afghanistan & $\begin{array}{l}\text { Deforestation, } \\
\text { Forest fragmentation }\end{array}$ & 1976-2014 & [93] \\
\hline 6 & 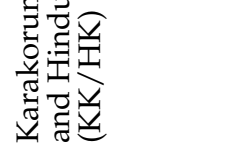 & Pakistan & $\begin{array}{l}\text { Built-up area increased } \\
\text { Cropland increased }\end{array}$ & $\begin{array}{l}2008-2018 \\
2000-2020\end{array}$ & [94] \\
\hline 7 & 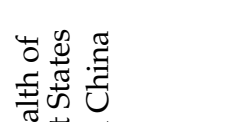 & Kazakhstan & $\begin{array}{l}\text { Vegetation cover decreased } \\
\text { Built-up area increased } \\
\text { Forest decreased }\end{array}$ & 1995-2015 & [95] \\
\hline 8 & 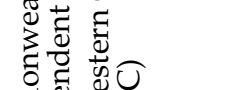 & Kyrgyzstan & $\begin{array}{l}\text { Barren land increased } \\
\text { Agriculture increased }\end{array}$ & 1996-2014 & [96] \\
\hline 9 & 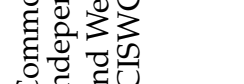 & Pamir mountains (Tajikistan) & $\begin{array}{l}\text { Deforestation } \\
\text { Desertification }\end{array}$ & - & [97] \\
\hline 10 & Uモદ & Uzbekistan & Grassland degradation & 1991-2010 & [98] \\
\hline 11 & 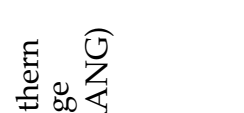 & Mongolia & Grassland degradation & $\begin{array}{l}2000-2006 \\
1998-2006\end{array}$ & $\begin{array}{l}{[99]} \\
{[100]}\end{array}$ \\
\hline 12 & 乙气二 & Altai region (Russia) & Land degradation & - & [101] \\
\hline
\end{tabular}

\subsection{Economic Factors}

\subsubsection{Habitat Fragmentation through Trade Corridors}

The Belt and Road Initiative (BRI), which was initiated by the Chinese government in 2013 to enhance regional connectivity and so economic development, is the largest infrastructure project in human history [102]. Recently, several studies along the different economic corridors, including the China-Mongolia-Russia Economic Corridor [103], the New Eurasia Land Bridge Economic Corridor [104], and the China-Pakistan Economic Corridor [105], identified the associated environmental issues. Other studies also concluded that BRI has potential negative impacts on the region's biodiversity as there are many plans for transportation development to expand into remote regions and ecosystems $[106,107]$.

\subsubsection{Unsustainable Tourism in the Snow Leopard Landscape}

Tourism is growing continuously and is primarily unregulated, which results in uncontrolled tourism in this region and creates many environmental problems for the fragile snow leopard landscape [108]. In addition, trophy hunting is a considerable incomeproducing recreational activity; yet this remains a controversial tool in conservation science with substantial benefits and risks. After initiation of trophy hunting programs, a conflict of interest arises between the local community and snow leopards. The trophy hunting of wild ungulates generates considerable income for the local community, giving rise to negative perceptions of the snow leopard as a pest animal because the snow leopard depends on the precious trophy ungulates as its prey and consequently destroys the local community's income generation potential [40]. Alternately, the wild trophy ungulates (Markhor, Ibex, blue sheep) in northern Pakistan provide enormous income to the local community; however, at the same time, the snow leopard depends on the abundance of ungulates to survive and increase its population [108]. This conflict and the associated 
adverse perceptions lead to problems that endanger the existence of snow leopards through the removal of wild prey species or other retaliatory killings [109].

\section{Implications of Snow Leopard Landscape Degradation}

\subsection{Political Implications}

\subsubsection{Implications Arising from Political Boundaries}

The snow leopard landscapes span some of the most sensitive and conflicted areas in the world, including Siachen glacier (highest battlefield in the world) between Pakistan and India [110]. The militarization of the fragile environment and armed conflicts are a major threat to the larger landscapes and have consequences for the environment [111]. Similarly, the disputed regions between China and India are prone to military buildup in the high-altitude snow leopard landscapes, thus degrading the fragile environment [112]. In addition, armed conflict is often detrimental to wildlife, and political emergencies have a negative impact on wildlife abundance. Asian landscapes have shown that there are consequences of military conflicts, including decreased enforcement abilities, decreased conservation and research activities, new trade routes for wildlife and natural resources, and the refuge effect, where people avoid conflict areas [113]. Certain snow leopard landscapes are areas with a long history of conflict, e.g., Afghanistan. This political situation may have serious consequences for Afghanistan's natural resources, and potentially for snow leopard populations.

\subsubsection{Implications Arising from Non-Uniform Conservation Policies}

Non-uniform conservation policies create further complications in managing issues at a larger regional level in addition to the increasing costs of managing an issue at the regional level [38]. Environmental problems are mostly transboundary and exceed the political boundaries of a country [114]. Different political contexts over the same landscape may create different pressures on the environment [115].

\subsection{Ecological Implications}

\subsubsection{Environmental Degradation}

The snow leopard is the top predator in the world's highest alpine tundra ecosystem and can help restore landscapes by maintaining a natural tropic cascade [116]. Snow leopards in the high Asian mountains are a balancing force for the alpine ecosystem's sustainability and provide ecosystem services that are required by the larger human population living downstream in Asia [116,117]. Thus, conservation of biological diversity has important consequences for the maintenance and continuous provision of the ecosystem services in these high Asian mountains [118]. These ecosystem services include supporting ecotourism by maintaining ecosystem quality $[119,120]$, biodiversity conservation, carbon sequestration, and recharging water for more than two billion people downstream [121,122]. However, previous studies revealed that, due to ecosystem degradation in the snow leopard landscapes, the corresponding ecosystem services are negatively impacted or lost $[86,123,124]$.

\subsubsection{Implication of Climate Change}

Climate change can affect the persistence of large wild species $[79,81]$ and their habitat through loss, degradation, and fragmentation of habitats [24,65,125]. Habitat loss, fragmentation, and degradation are responsible for species decline, leading to endangered status and extinction [84]. Climate change has impacts at the species level and, more significantly, at the landscape level [65]. Thus, a holistic approach is required to conserve the socio-ecological system in the snow leopard landscape.

\subsection{Social Implications}

In addition, other ecosystem services provided by mountains inhabited by snow leopards include sustaining agricultural and pastoral livelihoods, recreation, inspiration, and offering economic opportunities $[121,122,126]$. Loss of the snow leopard will result 
in the loss of ecosystem services and functions in Asia's highest mountain regions [126]. Degradation of the ecosystems in the snow leopard habitat region can impair ecosystem services in the long run [127].

\subsubsection{Human-Snow Leopard Conflict}

The livelihood of livestock owners depends on them selling their animals or is derived products. The depredation of valuable livestock by snow leopard deprives poor livestock owners of the primary and sometimes only source of income [44]. Retaliatory killings occur when the local community directly shoots or indirectly poisons the animals [50,51]. Ancillary unanticipated killings also occur, resulting from guidelines such as Chinese pest control policies that allow small mammals like the plateau Pika to be poisoned, which can be a source of poison to snow leopards [5]. An estimated 710 Snow leopards were killed from 2003-2016, although snow leopards may be killed in greater numbers and go unreported [52]. Thus, snow leopard killing and the subsequent decline in population is a critical cause for the degradation of the snow leopard landscape and the increasing vulnerability of the region.

\subsubsection{Increasing Human Population}

During the last five centuries, about 368 species of vertebrates have gone extinct due to direct or indirect anthropogenic impacts $[128,129]$. In addition, human disturbances are responsible for threatening a further $18 \%$ of vertebrates with extinction globally [128]. Human influences on habitat alteration and habitat fragmentation threaten species survival [130]. The increasing human population and encroachment into the wildlife habitat is forcing wild animals to live closer to human settlements $[5,94,123]$. The increasing human population has placed biodiversity under pressure [131]. The snow leopard has a large habitat requirement of about 100 to $1000 \mathrm{~km}^{2}$, and thus is influenced by the increasing human population [132].

\subsection{Economic Implications}

\subsubsection{Habitat Fragmentation through Trade Corridors}

Massive development projects connecting China with most of its neighbors through the building of mega infrastructure (Figure 4) are bisecting the global snow leopard range, contributing to the increasing vulnerability of the snow leopard population $[5,80,133]$. Thus, infrastructure connectivity, population growth, and increased trade with contiguous countries in the snow leopard global range will have significant impact [134,135], mainly through habitat fragmentation and the increasing human presence in the range $[8,136,137]$. Snow leopard habitat intrusion and destruction are caused by enormous infrastructure projects, including large dams, roads and highways, mining projects, tourist areas $[63,132,138]$, and the associated human activity/interference $[44,139,140]$.

Regarding specific case study concerns, it is thought that the BRI will increase illegal hunting and trade for large carnivore species due to increased access points throughout their ranges [141]. Increasing the expansion of international trade routes is thought to simultaneously facilitate greater access to and stimulate demand for trade in illegal wildlife, especially given existing ports fail to screen cargo extensively [142]. Fighting against the illegal wildlife trade is reliant on international mechanisms like The Convention on International Trade in Endangered Species of Wild Fauna and Flora (CITES) in efforts for international cooperation against overexploitation through a system to regulate international trade. The CITES falls short as a result of a lack of compliance and implementation on the ground in many countries, particularly in the least developed countries without an inadequate governmental structure, legislature, and enforcement capacity. 


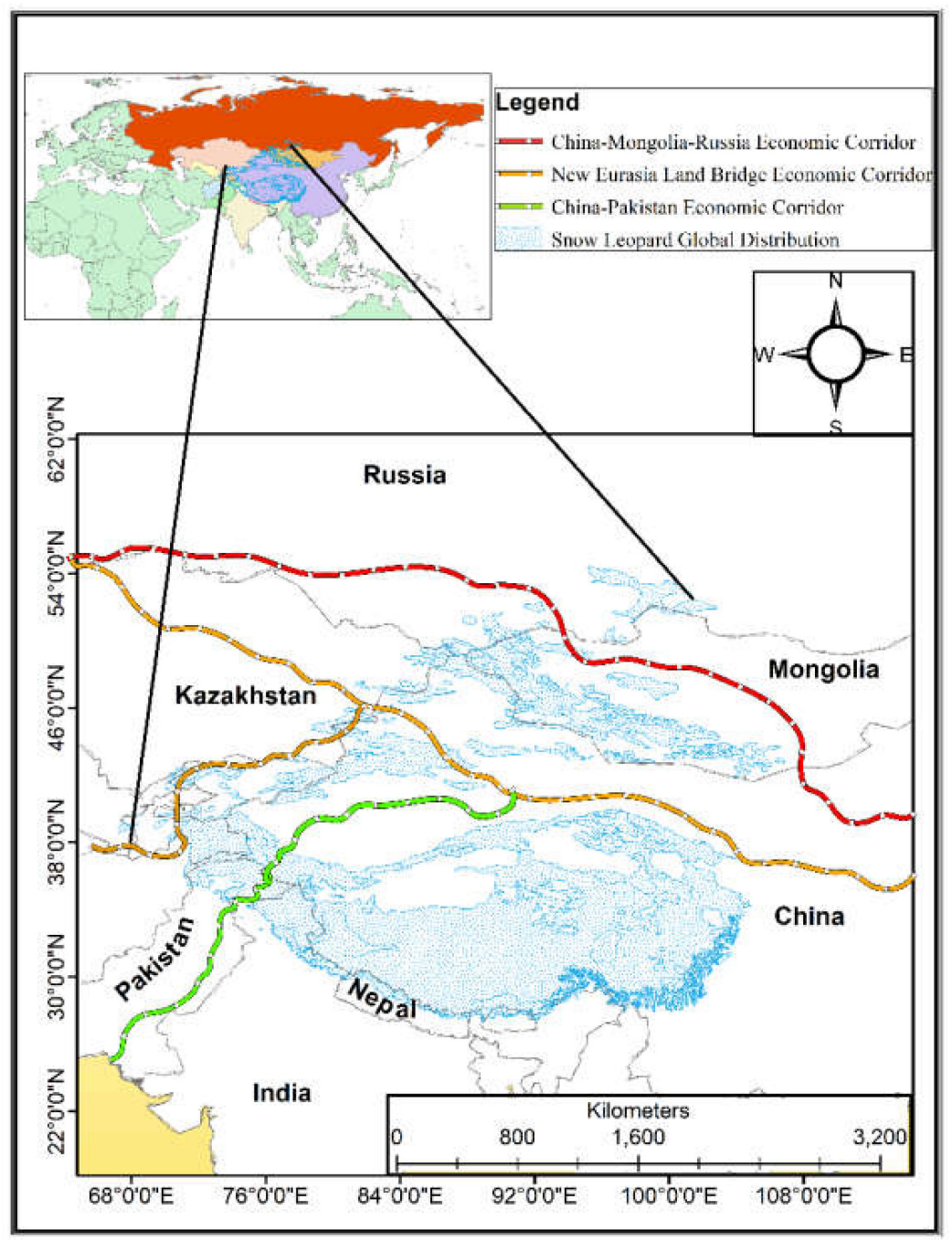

Figure 4. Identified Belt and Road Initiative (BRI) economic corridors are cutting through the snow leopard landscape in Asia resulting in increased vulnerability.

\subsubsection{Unsustainable Tourism in the Snow Leopard Landscape}

Uncontrolled tourism has negative consequences for the environment and degrades the environment [143,144]. Environmental degradation is partly due to the generation of solid waste pollution in the region [145]. Moreover, emissions from the transport vehicles of tourists are responsible for degrading the air quality [146]. Thus, mass tourism is associated with considerable cost in the form of ecosystem damages and threatens local biodiversity, ultimately degrading the ecosystem $[147,148]$.

\section{Possible Pathways to Handle Snow Leopard Transboundary Conservation Issues}

\subsection{Handling Political Boundaries Related Issues}

\subsubsection{Transboundary Collaboration (Regional Cooperation)}

Transnational environmental problems lack regional cooperation, specifically in Central and South Asia's snow leopard landscape [149], with similar challenges arising for SES for other transboundary countries across the snow leopard global habitat. Regional cooperation is further limited in the snow leopard landscape due to territorial disputes and other historical conflicts [150]. The cross-boundary nature of the snow leopard landscape provides an opportunity for transboundary cooperation among the range countries to achieve long-term conservation [151].

The most critical organization in the snow leopard range countries is the Shanghai Cooperation Organization (SCO) [152]. The SCO was the first international organization 
initiated by China and thus has a leading role in establishing functional international relationships [153]. The SCO comprises all the snow leopard range countries except for Bhutan (Figure 5). The SCO's core objective is to provide a better environment for socioeconomic development and regional prosperity [152,154]; the SCO platform was used previously to gradually shape relations among the member states [155]. Thus, the SCO can play an essential role in collaboration and the sustainable development of the snow leopard landscape. The SCO is driven and inspired by China, clearly depicting China as an emerging global power with a leadership role in regional or international affairs [153]. Notably, China covers around $60 \%$ of the snow leopard landscape worldwide. Thus, it has the opportunity to play a leading role in the sustainable development of this landscape.

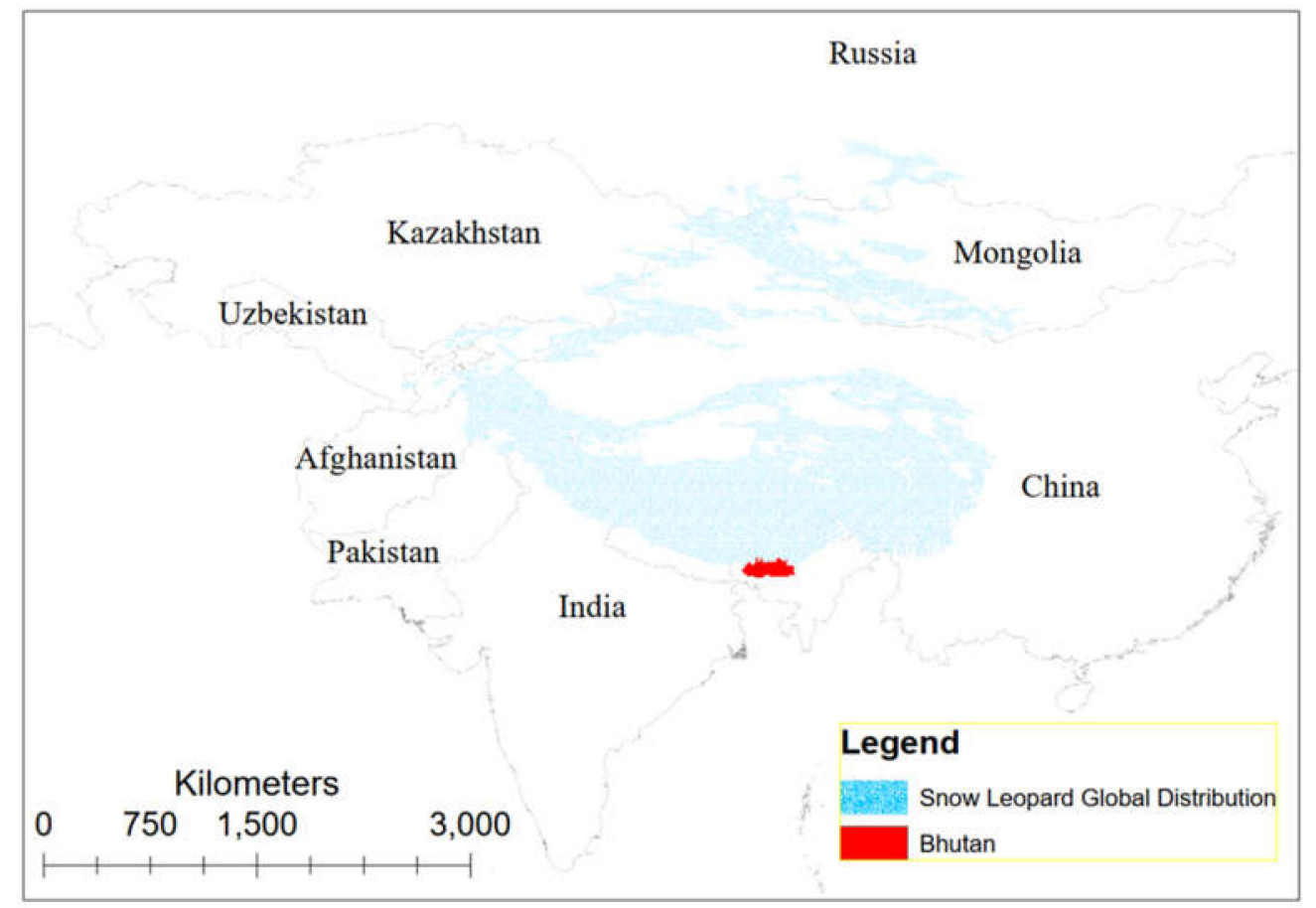

Figure 5. The snow leopard range countries are also connected through the Shanghai Cooperation Organization (SCO) except Bhutan.

\subsubsection{Creation of Peace Parks}

Resolving local transboundary conflicts often culminates in creating "peace parks" by designating a demilitarized peace park that would reinforce conflict resolution. Amid political differences in Afghanistan, India, China, Kyrgyzstan, Pakistan, and Tajikistan, conservationists brought about the conservation of the Pamir Wakhan [113]. The Karakoram mountains is a disputed region between India and Pakistan, and conservationists in this region suggested establishing Siachen peace park [110,156]. Similarly, the Khangchendzonga Conservation Area, in the Qomolangma Region, and the Altai Mountains could also serve as peace parks. Researchers have suggested that the further establishment of a peace park in the Himalayas region of Asia would prove to be an effective solution to resolve continued biodiversity loss as a result of war and military activities [157].

\subsubsection{Addressing Non-Uniform Conservation Policies}

The snow leopard landscape is often viewed within the totality of natural, human, and spiritual dimensions, and thus has been the focus of integrated interpretations, such as Coupled Socio-Ecological Systems (CSES) approaches [158]. Recently, the term SocioEcological System (SES) has been widely used to understand the human-nature relationship with the idea that an SES is interrelated and indivisible [159]. A regional landscape is a CSES composed of a dynamic mosaic of land uses and stakeholders [159,160]. Management 
of landscapes at the regional level thus requires a wide variety of interacting natural and human processes operating at different spatio-temporal scales [160]. Human behavior can affect the SES through complex human-environment interactions [161].

Previous studies disapproved conventional sectoral approaches condemning them as insufficient to address the multi-faceted changes occurring in an evolving socio-economic environment [162-164]. Integrative landscape management may provide solutions and alleviate global challenges by inviting cross-sectoral collaboration to mitigate vulnerability at a significant regional level [165]. More extensive landscape approaches for interorganizational goal-oriented networks and well-coordinated synergistic strategies have gained importance in terms of reconciling conservation and development [166].

Thus, sustainable landscapes incorporate complexity into the management process. Sayer et al. [166] framed 10 strategies for a landscape approach, including continual learning and adaptive management, a common concern entry point, multiple scales, multifunctionality, multiple stakeholders, negotiated and transparent change logic, clarification of rights and responsibilities, participatory and user-friendly monitoring, resilience, and strengthened stakeholder capacity. As a result, the landscape will be resistant to future disturbances caused by natural or anthropogenic sources.

\subsection{Handling Social Issues}

\subsubsection{Improving Livestock Management Practices}

The poor or lack of livestock guarding practices may lead to increasing snow leopard depredation on domestic livestock [133,167]. Previous studies demonstrated that proper livestock guarding can reduce snow leopard depredation of livestock $[1,26,168]$. Strong corrals for livestock can provide better protection for domestic livestock at night. Poor corrals may increase snow leopard depredation and losses of domestic livestock; therefore, better protection will provide better results $[26,167]$, thereby decreasing human-snow leopard conflict [167]. Livestock insurance schemes and compensation for livestock depredation can play a role in mitigating human-snow leopard conflict [169].

\subsubsection{Controlling Human Population Growth}

One of the vital approaches to managing biodiversity and human wellbeing is through reducing the population growth rate and finally reversing the population growth rate [170]. The population in most of the snow leopard range countries is growing at a fast rate [59,171]. Thus, controlling human population growth and managing the consumption pattern could reduce the impact of these factors [172].

\subsubsection{Payment for Ecosystem Services}

Recently, Payment for Ecosystem Services (PES) represents a vital conservation policy $[173,174]$. PES programs have seen a swift increase in recent decades [175]. PES are defined as voluntary transactions in which ecosystem services are bought and sold between beneficiaries and service providers [176]. The global snow leopard landscape provides ecosystem services to more than two billion people $[121,177]$. PES is an excellent tool with which to obtain the local communities' support for environmental conservation [178].

\subsection{Handling Ecological Issues}

4.3.1. Climate Change Mitigation (Climate-Smart Technologies and NatureBased Solutions)

Climate change is an essential factor contributing to vulnerability in this region. Thus, the adoption of innovative solutions, including climate-smart technologies and naturebased solutions, is a promising option. These innovative solutions can play a significant role in mitigating the vulnerability of the Himalayan region $[179,180]$. Studies in the snow leopard range countries have revealed that climate-smart technologies are some of the best options available for vulnerability mitigation [181-183]. Prior studies revealed that 
restoring natural predators in a landscape can mitigate climate changes and predators can serve as insurance against climate change [184,185].

\subsubsection{Integrative Management of Transboundary Conservation Landscape}

Transboundary conservation efforts are also strengthened by the Global Snow Leopard and Ecosystem Protection Programme (GSLEP), launched in October 2013 with the adoption of the Bishkek Declaration of the Conservation of Snow Leopards, supporting the 12 range countries to develop national programs [186]. The group has become increasingly active after the establishment of an online platform that allows for trainings in targeted topics for representatives from snow leopard countries, as well as ongoing efforts to build global capacity for snow leopards. Transboundary collaboration provides an opportunity for the neighboring countries to conserve biodiversity across vast landscapes and reduce conservation costs [31]. For conservation of transboundary landscapes and biological diversity, collective efforts from the range countries are required to achieve the common goals [187].

\subsection{Handling Economic Issues}

\subsubsection{Environment-Friendly Trade Corridors in the Snow Leopard Landscape}

The transition of the current development in this region to green growth is a good step in achieving the sustainable development goals, which will lead to the protection and conservation of the environment, and promote biodiversity in the region. The BRI has promoted cooperation among the countries as regards different global issues like climate change mitigation [188,189]. A recent study by Cuiyun and Chazhong [190] revealed that the BRI's green development will provide long-term benefits for this region. However, the environmental impacts and recommended mitigations rarely provide sufficient safeguards, even when urgent priorities exist to provide proactive approaches for smart infrastructure planning to minimize impacts on snow leopards and other wildlife during the planning process [191]. Recommendations have been previously developed to shift these destructive patterns for protected areas and large mammals, to encourage BRI development partners and partner countries to support protected areas, to strategize wildlife corridors, to enact conservation planning methods, and to encourage transboundary and international collaborative efforts [107]. In 2017, an attempt to make the BRI more environment-friendly was developed, with the aim of promoting the construction of environment-friendly infrastructure, and promoting green trade and financing, and sustainable production and consumption among the partner countries [192]. CITES protections should scale with the scope of the BRI and tackle the complex issues surrounding the illegal wildlife trade for all protected species. Ongoing development scenarios can calibrate the planning process through science-policy interfaces at the local governmental planning and biodiversity conservation levels, using methodologies such as preemptive measures for smart or green planning.

\subsubsection{Sustainable Tourism}

Ecotourism is the best option for areas with wildlife availability and easy accessibility for tourists [193]. Sustainable tourism is economically viable, socially equitable, and ecologically sustainable [194]. Tourism is a good conservation tool if managed sustainably, especially in areas with apex predators [195]. A previous study on the snow leopard global range revealed ecotourism to be a good option for conservation in these high Asian landscapes [196].

\section{Conclusions and Recommendations}

Conservation of the snow leopard landscape is possible if there is political will among countries to establish transboundary collaboration and create peace parks in the border regions. These initiatives are required and other political differences must be put aside. Sustainable tourism and managing the increasing human population will have long lasting effect on the global snow leopard landscape. Similarly, sound land use planning in each 
country to avoid encroachment into the snow leopard and its prey species' habitat for mining, tourism, infrastructure, and agriculture is of utmost importance to reduce the survival threat to this vulnerable species. Opportunities can be created for the payment of ecosystem services and transnational conservation policies should be made more congruent. Other options include focusing on improving livestock management practices, controlling human population growth, climate change mitigation, creating transboundary conservation landscapes, establishing environment-friendly trade corridors, and adopting sustainable tourism. Similarly, previous studies in other regions found stakeholder awareness, stakeholder participation, and complex management systems to be other possible options [197-199].

The SCO is the leading international organization for the countries in this region, excepting Bhutan. The SCO can play an essential role in regional cooperation to promote economic development and ecological protection. As a leading country and founder of the SCO, China can play an influential role in this region's economic growth and environmental security. China covers almost $60 \%$ of the snow leopard habitat region. China can promote sustainable development in this region through effective conservation policies. Collaboration among partner countries in forums, such as the ICIMOD (The International Centre for Integrated Mountain Development), frequent communication between the stakeholder countries, and transboundary visits from stakeholder agencies and habitat resident communities in order to learn from each other are recommended. Holistic and cross-sectoral policies for the conservation of this SES will support the ecosystem and human development.

Author Contributions: Conceptualization, H.S., W.R. and I.u.R.; methodology, J.S. and M.N.; software, S.R. and M.T.K.; validation, I.A.S. and H.H.; formal analysis, W.R.; investigation, M.N.; resources, H.H.; data curation, E.B.; writing-original draft preparation, H.S. and W.R.; writing-review and editing, J.S. and E.B.; visualization, S.R.; supervision, I.u.R. and M.N.; project administration, H.S.; funding acquisition, W.R. and A.A.-M. All authors have read and agreed to the published version of the manuscript.

Funding: This research was funded by China Scholarship Council, grant to Hameeda Sultan (CSC No. 201839180002).

Informed Consent Statement: Not applicable for studies not involving humans.

Acknowledgments: We would like to thank two anonymous reviewers whose comments have helped to improve the manuscript.

Conflicts of Interest: The authors declare no conflict of interest. The funders had no role in the design of the study; in the collection, analyses, or interpretation of data; in the writing of the manuscript, or in the decision to publish the results.

\section{References}

1. Rashid, W.; Shi, J.; Rahim, I.U.; Sultan, H.; Dong, S.; Ahmad, L. Research trends and management options in human-snow leopard conflict. Biol. Conserv. 2020, 242, 108413. [CrossRef]

2. Anwar, M.B.; Jackson, R.; Nadeem, M.S.; Janečka, J.E.; Hussain, S.; Beg, M.A.; Muhammad, G.; Qayyum, M. Food habits of the snow leopard Panthera uncia (Schreber, 1775) in Baltistan, Northern Pakistan. Eur. J. Wildl. Res. 2011, 57, 1077-1083. [CrossRef]

3. Sunquist, F.; Sunquist, M. The Wild Cat Book; The University of Chicago Press: Chicago, IL, USA; London, UK, 2014 ; p. 277. [CrossRef]

4. Aryal, A.; Brunton, D.; Ji, W.; Karmacharya, D.; McCarthy, T.; Bencini, R.; Raubenheimer, D. Multipronged strategy including genetic analysis for assessing conservation options for the snow leopard in the central Himalaya. J. Mammal. 2014, 95, 871-881. [CrossRef]

5. Alexander, J.S.; Cheng, Z.C.; Kun, S.; Riordan, P. A spotlight on snow leopard conservation in China. Integr. Zool. 2016, 11, 308-321. [CrossRef]

6. Alexander, J.S.; Cusack, J.J.; Pengju, C.; Kun, S.; Riordan, P. Conservation of snow leopards: Spill-over benefits for other carnivores? Oryx 2016, 50, 239-243. [CrossRef]

7. McCarthy, T.M.; Fuller, T.K.; Munkhtsog, B. Movements and activities of snow leopards in Southwestern Mongolia. Biol. Conserv. 2005, 124, 527-537. [CrossRef] 
8. Riordan, P.; Cushman, S.A.; Mallon, D.; Shi, K.; Hughes, J. Predicting global population connectivity and targeting conservation action for snow leopard across its range. Ecography 2016, 38, 419-426. [CrossRef]

9. Li, J.; Schaller, G.B.; McCarthy, T.M.; Wang, D.; Jiagong, Z.; Cai, P.; Basang, L.; Lu, Z. A Communal Sign Post of Snow Leopards (Panthera uncia) and Other Species on the Tibetan Plateau, China. Int. J. Biodivers. 2013, 2013, 370905. [CrossRef]

10. Sharma, R.K.; Bhatnagar, Y.V.; Mishra, C. Does livestock benefit or harm snow leopards? Biol. Conserv. 2015, 190, 8-13. [CrossRef]

11. Li, J.; Mccarthy, T.M.; Wang, H.; Weckworth, B.V.; Schaller, G.B.; Mishra, C.; Lu, Z.; Beissinger, S.R. Climate refugia of snow leopards in High Asia. Biol. Conserv. 2016, 203, 188-196. [CrossRef]

12. Bagchi, S.; Sharma, R.K.; Bhatnagar, Y.V. Change in snow leopard predation on livestock after revival of wild prey in the Trans-Himalaya. Wildl. Biol 2020, 1, 1-11. [CrossRef]

13. Bitabarova, A.G. Unpacking Sino-Central Asian engagement along the New Silk Road: A case study of Kazakhstan. J. Contemp. East Asia Stud. 2019, 7, 149-173. [CrossRef]

14. Farrington, J.D.; Tsering, D. Human-snow leopard conflict in the Chang Tang region of Tibet, China. Biol. Conserv. 2019, 237, 504-513. [CrossRef]

15. González-Tokman, D.; Córdoba-Aguilar, A.; Dáttilo, W.; Lira-Noriega, A.; Sánchez-Guillén, R.A.; Villalobos, F. Insect responses to heat: Physiological mechanisms, evolution and ecological implications in a warming world. Biol. Rev. 2020, 95, 802-821. [CrossRef] [PubMed]

16. Lewis, M.; Songster, E.E. Studying the snow leopard: Reconceptualizing conservation across the China-India border. Br. J. Hist. Sci. 2016, 1, 169-198. [CrossRef]

17. Li, J.; Weckworth, B.V.; McCarthy, T.M.; Liang, X.; Liu, Y.; Xing, R.; Li, D.; Zhang, Y.; Xue, Y.; Jackson, R.; et al. Defining priorities for global snow leopard conservation landscapes. Biol. Conserv. 2020, 241, 108387. [CrossRef]

18. Teo, H.C.; Lechner, A.M.; Walton, G.W.; Chan, F.K.S.; Cheshmehzangi, A.; Tan-Mullins, M.; Chan, H.K.; Sternberg, T.; CamposArceiz, A. Environmental Impacts of Infrastructure Development under the Belt and Road Initiative. Environments $2019,6,72$. [CrossRef]

19. Cumming, G.S.; Peterson, G.D. Unifying Research on Social-Ecological Resilience and Collapse. Trends Ecol. Evol. 2017, 32, 695-713. [CrossRef]

20. Lauerburg, R.A.M.; Diekmann, R.; Blanz, B.; Gee, K.; Held, H.; Kannen, A.; Möllmann, C.; Probst, W.N.; Rambo, H.; Cormier, R.; et al. Socio-ecological vulnerability to tipping points: A review of empirical approaches and their use for marine management. Sci. Total Environ. 2020, 705, 135838. [CrossRef]

21. Penjor, U.; Wangdi, S.; Tandin, T.; Macdonald, D.W. Vulnerability of mammal communities to the combined impacts of anthropic land-use and climate change in the Himalayan conservation landscape of Bhutan. Ecol. Indic. 2021, 121, 107085. [CrossRef]

22. Mukherji, A.; Sinisalo, A.; Nüsser, M.; Garrard, R.; Eriksson, M. Contributions of the cryosphere to mountain communities in the Hindu Kush Himalaya: A review. Reg. Environ. Chang. 2019, 19, 1311-1326. [CrossRef]

23. Trouwborst, A.; Blackmore, A. Hot Dogs, Hungry Bears, and Wolves Running Out of Mountain-International Wildlife Law and the Effects of Climate Change on Large Carnivores. J. Int. Wildl. Law Policy 2020, 23, 212-238. [CrossRef]

24. Forrest, J.L.; Wikramanayake, E.; Shrestha, R.; Areendran, G.; Gyeltshen, K.; Maheshwari, A.; Mazumdar, S.; Naidoo, R.; Thapa, G.J.; Thapa, K. Conservation and climate change: Assessing the vulnerability of snow leopard habitat to treeline shift in the Himalaya. Biol. Conserv. 2012, 150, 129-135. [CrossRef]

25. Hanson, J.H.; Schutgens, M.; Leader-Williams, N. What factors best explain attitudes to snow leopards in the Nepal Himalayas? PLOS ONE 2019, 14, e0223565. [CrossRef] [PubMed]

26. Jackson, R.M.; Wangchuk, R. A Community-Based Approach to Mitigating Livestock Depredation by Snow Leopards. Hum. Dimens. Wildl. 2004, 9, 307-315. [CrossRef]

27. Jamwal, P.S.; Takpa, J.; Parsons, M.H. Factors contributing to a striking shift in human-wildlife dynamics in Hemis National Park, India: 22 years of reported snowleopard depredation. Oryx 2017, 53, 58-62. [CrossRef]

28. Laterra, P.; Barral, P.; Carmona, A.; Nahuelhual, L. Focusing Conservation Efforts on Ecosystem Service Supply May Increase Vulnerability of Socio-Ecological Systems. PLOS ONE 2016, 11, e0155019. [CrossRef]

29. Goursi, U.H.; Anwar, M.; Bosso, L.; Nawaz, M.A.; Kabir, M. Spatial distribution of the threatened Asiatic black bear in northern Pakistan. Ursus 2021, 32, 1-5. [CrossRef]

30. Berrouet, L.M.; Machado, J.; Villegas-Palacio, C. Vulnerability of socio-ecological systems: A conceptual Framework. Ecol. Indic. 2018, 84, 632-647. [CrossRef]

31. Liu, J.; Yong, D.L.; Choi, C.-Y.; Gibson, L. Transboundary Frontiers: An Emerging Priority for Biodiversity Conservation. Trends Ecol. Evol. 2020, 35, 679-690. [CrossRef]

32. Saddiki, S. Border fencing in India: Between colonial legacy and changing security challenges. Int. J. Arts Sci. 2016, 7, 111-124.

33. Ellison, A.M. Political borders should not hamper wildlife. Nature 2014, 508, 9. [CrossRef] [PubMed]

34. Leki; Thinley, P.; Rajaratnam, R.; Shrestha, R. Establishing baseline estimates of blue sheep (Pseudois nayaur) abundance and density to sustain populations of the vulnerable snow leopard (Panthera uncia) in Western Bhutan. Wildl. Res. 2018, 45, 38-46. [CrossRef]

35. Xu, F.; Ma, M.; Yang, W.; Blank, D.; Wu, Y.; Mccarthy, T.; Munkhtsog, B. Winter habitat use of snow leopards in Tomur National Nature Reserve of Xinjiang, Northwest China. J. Arid. Land 2012, 4, 191-195. [CrossRef] 
36. Vitkalova, A.V.; Feng, L.; Rybin, A.N.; Gerber, B.D.; Miquelle, D.G.; Wang, T.; Yang, H.; Shevtsova, E.I.; Aramilev, V.V.; Ge, J. Transboundary cooperation improves endangered species monitoring and conservation actions: A case study of the global population of Amur leopards. Conserv. Lett. 2018, 11, e12574. [CrossRef]

37. Janecka, J.E.; Yu-guang, Z.; Di-qiang, L.; Munkhtsog, B.; Bayaraa, M.; Galsandorj, N.; Wangchuk, T.R.; Karmacharya, D.; McCarthy, T.; Li, J.; et al. Range-Wide Snow Leopard Phylogeography Supports Three Subspecies. J. Hered. 2017, 108, 597-607. [CrossRef]

38. Cherp, A. Cost of non-uniform climate policies. Nat. Clim. Chang. 2021, 11, 722-723. [CrossRef]

39. Calvin, K.; Clarke, L.; Krey, V.; Blanford, G.; Jiang, K.; Kainuma, M.; Kriegler, E.; Luderer, G.; Shukla, P.R. The role ofAsia in mitigating climate change: Results from the Asia modeling exercise. Energy Econ. 2012, 34, S251-S260. [CrossRef]

40. Kachel, S.M.; Mccarthy, K.P.; Mccarthy, T.M.; Oshurmamadov, N. Investigating the potential impact of trophy hunting of wild ungulates on snow leopard Panthera uncia conservation in Tajikistan. Oryx 2017, 51, 597-604. [CrossRef]

41. Khatoon, R.; Hussain, I.; Anwar, M.; Nawaz, M.A. Diet selection of snow leopard (Panthera uncia) in Chitral, Pakistan. Turk. J Zool. 2017, 41, 914-923. [CrossRef]

42. Rosen, T.; Hussain, S.; Mohammad, G.; Jackson, R.; Janecka, J.E.; Michel, S. Reconciling Sustainable Development of Mountain Communities With Large Carnivore Conservation. Mt. Res. Dev. 2012, 32, 286-293. [CrossRef]

43. Khan, M.Z.; Awan, S.; Khan, B.; Abbas, S.; Ali, A. A review of behavioural ecology and conservation of large predators inhabiting the Central Karakoram National Park (CKNP). J. Biodivers. Environ. Sci. 2014, 5, 439-446.

44. Sharma, K.; Bayrakcismith, R.; Tumursukh, L.; Johansson, O.; Sevger, P.; McCarthy, T.; Mishra, C. Vigorous dynamics underlie a stable population of the endangered snow leopard Panthera uncia in Tost Mountains, South Gobi, Mongolia. PLoS ONE 2014, 9, e101319. [CrossRef] [PubMed]

45. Khan, M.Z.; Khan, B.; Awan, M.S.; Begum, F. Livestock depredation by large predators and its implications for conservation and livelihoods in the Karakoram Mountains of Pakistan. Oryx 2017, 52, 519-525. [CrossRef]

46. Suryawanshi, K.R.; Bhatnagar, Y.V.; Redpath, S.; Mishra, C. People, predators and perceptions: Patterns of livestock depredation by snow leopards and wolves. J. Appl. Ecol. 2013, 50, 550-560. [CrossRef]

47. Aryal, A.; Brunton, D.; Ji, W.; Barraclough, R.K.; Raubenheimer, D. Human-carnivore conflict: Ecological and economical sustainability of predation on livestock by snow leopard and other carnivores in the Himalaya. Sustain. Sci. 2014, 9, 321-329. [CrossRef]

48. Bashari, M.; Sills, E.; Peterson, M.N.; Cubbage, F. Hunting in Afghanistan: Variation in motivations across species. Oryx 2017, 52, 526-536. [CrossRef]

49. Li, J.; Xiao, L.; Lu, Z. Challenges of snow leopard conservation in China. Sci. China (Life Sci.) 2016, 59, 637-639. [CrossRef] [PubMed]

50. Sangay, T.; Vernes, K. Human-wildlife conflict in the Kingdom of Bhutan: Patterns of livestock predation by large mammalian carnivores. Biol. Conserv. 2008, 141, 1272-1282. [CrossRef]

51. Chen, P.; Gao, Y.; Lee, A.T.L.; Cering, L.; Shi, K.; Clark, S.G. Human-carnivore coexistence in Qomolangma (Mt. Everest) Nature Reserve, China: Patterns and compensation. Biol. Conserv. 2016, 197, 18-26. [CrossRef]

52. Namgail, T.; Fox, J.L.; Bhatnagar, Y.V. Carnivore-Caused Livestock Mortality in Trans-Himalaya. Environ. Manage. 2007, 39, 490-496. [CrossRef] [PubMed]

53. Chetri, M.; Odden, M.; Devineau, O.; Wegge, P. Patterns of livestock depredation by snow leopards and other large carnivores in the Central Himalayas, Nepal. Glob. Ecol. Conserv. 2019, 17, 1-11. [CrossRef]

54. Simms, A.; Moheb, Z.; Salahudin; Ali, H.; Ali, I.; Wood, T. Saving threatened species in Afghanistan: Snow leopards in the Wakhan Corridor. Int. J. Environ. Stud. 2011, 68, 299-312. [CrossRef]

55. Esipov, A.; Bykova, E.; Protas, Y.; Aromov, B. Central Asia: Uzbekistan. In SNOW LEOPARDS, Biodiversity of the World: Conservation from Genes to Landscapes; McCarthy, T., Mallon, D., Eds.; Academic Press: London, UK, 2016; pp. 439-448. [CrossRef]

56. Mijiddorj, T.N.; Alexander, J.S.; Samelius, G. Livestock depredation by large carnivores in the South Gobi, Mongolia. Wildl. Res. 2018, 45, 237-247. [CrossRef]

57. Paltsyn, M.; Poyarkov, A.; Spitsyn, S.; Kuksin, A.; Istomov, S.; Gibbs, J.P.; Jackson, R.M.; Castner, J.; Kozlova, S.; Karnaukhov, A.; et al. Northern Range: Russia. In SNOW LEOPARDS, Biodiversity Of The World: Conservation From Genes To Landscapes; McCarthy, T.M., Mallon, D., Eds.; Academic Press: London, UK, 2016; pp. 488-498. [CrossRef]

58. Cardillo, M.; Purvis, A.; Sechrest, W.; Gittleman, J.L.; Bielby, J.; Mace, G.M. Human Population Density and Extinction Risk in the World's Carnivores. PLoS Biol. 2004, 2, 909-914. [CrossRef]

59. Cui, K.; Shoemaker, S.P. A look at food security in China. npj Sci. Food 2018, 2, 4. [CrossRef]

60. Chauhan, R.K.; Mohanty, S.K.; Mishra, U.S. Population Trends, Distribution and Prospects in the Districts of India. In The Demographic and Development Divide in India: A District-Level Analyses; Mohanty, S.K., Mishra, U.S., Chauhan, R.K., Eds.; Springer: Singapore, 2019; pp. 17-144. [CrossRef]

61. Abbas, S. Global warming and export competitiveness of agriculture sector: Evidence from heterogeneous econometric analysis of Pakistan. Environ. Sci. Pollut. R. 2022. [CrossRef]

62. Luck, G.W. A review of the relationships between human population density and biodiversity. Biol. Rev. 2007, 82, 607-645. [CrossRef]

63. Alexander, J.S.; Gopalaswamy, A.M.; Shi, K.; Hughes, J.; Riordan, P. Patterns of Snow Leopard Site Use in an Increasingly Human-Dominated Landscape. PLoS ONE 2016, 11, e0155309. [CrossRef] 
64. Klausmeyer, K.R.; Shaw, M.R.; Mackenzie, J.B.; Cameron, D.R. Landscape-scale indicators of biodiversity's vulnerability to climate change. Ecosphere 2011, 2, 1-18. [CrossRef]

65. Ye, X.; Yu, X.; Yu, C.; Tayibazhaer, A.; Xu, F.; Skidmore, A.K.; Wang, T. Impacts of future climate and land cover changes on threatened mammals in the semi-arid Chinese Altai Mountains. Sci. Total Environ. 2018, 612, 775-787. [CrossRef] [PubMed]

66. Farrington, J.D.; Li, J. Climate Change Impacts on Snow Leopard Range. In SNOW LEOPARDS, Biodiversity of the World: Conservation from Genes to Landscapes; McCarthy, T.M., Mallon, D., Eds.; Academic Press: London, UK, 2016; pp. 85-95. [CrossRef]

67. IPCC. Climate Change 2013: The Physical Science Basis; Intergovernmental Panel on Climate Change: Cambridge, UK; New York, NY, USA, 2013; pp. 1-222.

68. IPCC. Climate Change 2021 The Physical Science Basis; Intergovernmental Panel on Climate Change: Cambridge, UK; New York, NY, USA, 2021; pp. 1-223.

69. Asad, F.; Zhu, H.; Zhang, H.; Liang, E.; Muhammad, S.; Farhan, S.B.; Hussain, I.; Wazir, M.A.; Ahmed, M.; Esper, J. Are Karakoram temperatures out of phase compared to hemispheric trends? Clim. Dyn. 2017, 48, 3381-3390. [CrossRef]

70. Spies, M. Mixed manifestations of climate change in high mountains: Insights from a farming community in northern Pakistan. Clim. Dev. 2020, 12, 911-922. [CrossRef]

71. Kakinuma, K.; Yanagawa, A.; Sasaki, T.; Rao, M.P.; Kanae, S. Socio-ecological Interactions in a Changing Climate: A Review of the Mongolian Pastoral System. Sustainability 2019, 11, 5883. [CrossRef]

72. Sorg, A.; Bolch, T.; Stoffel, M.; Solomina, O.; Beniston, M. Climate change impacts on glaciers and runoff in Tien Shan (Central Asia). Nat. Clim. Chang. 2012, 2, 725-731. [CrossRef]

73. Kokorin, A.O. Assessment Report Climate Change and Its Impact on Ecosystems, Population and Economy of the Russian Portion of the Altai-Sayan Ecoregion; WWF Russia: Moscow, Russia, 2011.

74. Talipova, E.; Shrestha, S.; Alimkulov, S.; Nyssanbayeva, A.; Tursunova, A.; Isakan, G. Influence of climate change and anthropogenic factors on the Ile River basin streamflow, Kazakhstan. Arab. J. Geosci. 2021, 14, 1-14. [CrossRef]

75. Marchenko, S.S.; Gorbunov, A.P.; Romanovsky, V.E. Permafrost warming in the Tien shan Mountains, Central Asia. Glob. Planet. Chang. 2007, 56, 311-327. [CrossRef]

76. Kholmatjanov, B.M.; Sulaymonova, N.N.; Petrov, Y.V.; Khujanazarov, T.; Abdikulov, F.I.; Tanaka, K. Analysis of Temperature Change in Uzbekistan and the Regional Atmospheric Circulation of Middle Asia during 1961-2016. Climate 2020, 8, 101. [CrossRef]

77. Haag, I.; Kassam, K.-A.; Senftl, T.; Zandler, H.; Samimi, C. Measurements meet human observations: Integrating distinctive ways of knowing in the Pamir Mountains of Tajikistan to assess local climate change. Clim. Chang. 2021, 165, 1-22. [CrossRef]

78. Liu, X.; Chen, B. Climatic warming in the Tibetan Plateau during recent decades. Int. J. Climatol. 2000, 20, 1729-1742. [CrossRef]

79. Yang, X.; Zhang, T.; Qin, D.; Kang, S.; Qin, X. Characteristics and changes in air temperature and glacier's response on the north slope of Mt. Qomolangma (Mt. Everest). Arct. Antarct. Alp. Res. 2011, 43, 147-160. [CrossRef]

80. Adnan, M.; Nabi, G.; Kang, S.; Zhang, G.; Adnan, R.M.; Anjum, M.N.; Iqbal, M.; Ali, A.F. Snowmelt Runoff Modelling under Projected Climate Change Patterns in the Gilgit River Basin of Northern Pakistan. Pol. J. Environ. Stud. 2017, 26, 525-542. [CrossRef]

81. Sabin, T.P.; Krishnan, R.; Vellore, R.; Priya, P.; Borgaonkar, H.P.; Singh, B.B.; Sagar, A. Climate Change Over the Himalayas. In Assessment of Climate Change Over the Indian Region; Krishnan, R., Sanjay, J., Gnanaseelan, C., Mujumdar, M., Kulkarni, A., Chakraborty, S., Eds.; Springer Nature Singapore: Singapore, 2020; pp. 207-222. [CrossRef]

82. Shrestha, A.B.; Wake, C.P.; Mayewski, P.A.; Dibb, J.E. Maximum temperature trends in the Himalaya and its vicinity: An analysis based on temperature records from Nepal for the period 1971-1994. J. Clim. 1999, 12, 2775-2786. [CrossRef]

83. Khurshid, M.; Nafees, M.; Rahim, I.u.; Rashid, W. Impacts of Agriculture Land use Changes on Mobile Pastoral System in Naran Valley of Western Himalayan Northern Pakistan. Sarhad J. Agric. 2016, 32, 1-8. [CrossRef]

84. Sharma, K.; Robeson, S.M.; Thapa, P.; Saikia, A. Land-use/land-cover change and forest fragmentation in the Jigme Dorji National Park, Bhutan. Phys. Geogr. 2016, 38, 18-35. [CrossRef]

85. Cui, X.; Graf, H.-F. Recent land cover changes on the Tibetan Plateau: A review. Clim. Chang. 2009, 94, 47-61. [CrossRef]

86. Liu, S.; Zamanian, K.; Schleuss, P.-M.; Zarebanadkouki, M.; Kuzyakov, Y. Degradation of Tibetan grasslands: Consequences for carbon and nutrient cycles. Agric. Ecosyst. Environ. 2018, 252, 93-104. [CrossRef]

87. Gilani, H.; Shrestha, H.L.; Murthy, M.S.R.; Phuntso, P.; Pradhan, S.; Bajracharya, B.; Shrestha, B. Decadal land cover change dynamics in Bhutan. J. Environ. Manag. 2015, 148, 91-100. [CrossRef]

88. Dame, J.; Schmidt, S.; Müller, J.; Nüsser, M. Urbanisation and socio-ecological challenges in high mountain towns: Insights from Leh (Ladakh), India. Landsc. Urban Plan. 2019, 189, 189-199. [CrossRef]

89. Zhang, B.; Zhou, W. Spatial-Temporal Characteristics of Precipitation and Its Relationship with Land Use/Cover Change on the Qinghai-Tibet Plateau, China. Land 2021, 10, 269. [CrossRef]

90. Yar, P.; Huafu, J.; Khan, M.A.; Rashid, W.; Khan, S. Modification of Land Use/Land Cover and Its Impact on Groundwater in Peshawar City, Pakistan. J. Indian Soc. Remote Sens. 2022, 50, 159-174. [CrossRef]

91. Munsi, M.; Malaviya, S.; Oinam, G.; Joshi, P.K. A landscape approach for quantifying land-use and land-cover change (1976-2006) in middle Himalaya. Reg. Environ. Chang. 2010, 10, 145-155. [CrossRef]

92. Panta, M.; Kim, K.; Joshi, C. Temporal mapping of deforestation and forest degradation in Nepal: Applications to forest conservation. For. Ecol. Manag. 2008, 256, 1587-1595. [CrossRef] 
93. Reddy, C.S.; Saranya, K.R.L. Earth observation data for assessment of nationwide land cover and long-term deforestation in Afghanistan. Glob. Planet. Chang. 2017, 155, 115-164. [CrossRef]

94. Rashid, W.; Shi, J.; Rahim, I.U.; Qasim, M.; Baloch, M.N.; Bohnett, E.; Yang, F.; Khan, I.; Ahmad, B. Modelling Potential Distribution of Snow Leopards in Pamir, Northern Pakistan: Implications for Human-Snow Leopard Conflicts. Sustainability 2021, $13,13229$. [CrossRef]

95. Qi, J.; Tao, S.; Pueppke, S.G.; Espolov, T.E.; Beksultanov, M.; Chen, X.; Cai, X. Changes in land use/land cover and net primary productivity in the transboundary Ili-Balkhash basin of Central Asia, 1995-2015. Environ. Res. Commun. 2019, 2, 1-15. [CrossRef]

96. Duulatov, E.; Xi, C.; Kurban, A.; Ndayisaba, B.; Monoldorova, A. Detecting Land Use/Land Cover change using Landsat Imagery: Jumgal District, Kyrgyzstan. Int. J. Geoinform. 2016, 12, 1-7. [CrossRef]

97. Breckle, S.-W.; Wuchere, W. Vegetation of the Pamir (Tajikistan): Land use and desertification problems. In Land Use Change and Mountain Biodiversity; Spehn, E.M., Liberman, M., Körner, C., Eds.; CRC Press (Taylor \& Francis Group): Boca Raton, FL, USA, 2006; pp. 225-238.

98. Yang, Y.; Wang, Z.; Li, J.; Gang, C.; Zhang, Y.; Zhang, Y.; Odeh, I.; Qi, J. Comparative assessment of grassland degradation dynamics in response to climate variation and human activities in China, Mongolia, Pakistan and Uzbekistan from 2000 to $2013 . J$. Arid Environ. 2016, 135, 164-172. [CrossRef]

99. Sekiyama, A.; Takeuchi, W.; Shimada, S. Detection of Grassland Degradation Using MODIS Data in Mongolia. J. Arid. Land Stud. 2014, 24, 175-178.

100. Sternberg, T.; Tsolmon, R.; Middleton, N.; Thomas, D. Tracking desertification on the Mongolian steppe through NDVI and field-survey data. Int. J. Digit. Earth 2011, 4, 50-64. [CrossRef]

101. Milanova, E. Land use/cover change in Russia within the context of global challenges. Rom. J. Geogr. 2012, 56, 105-116.

102. Ng, L.S.; Campos-Arceiz, A.; Sloan, S.; Hughes, A.C.; Tiang, D.C.F.; Li, B.V.; Lechner, A.M. The scale of biodiversity impacts of the Belt and Road Initiative in Southeast Asia. Biol. Conserv. 2020, 248, 108691. [CrossRef]

103. Dong, S.; Li, Y.; Li, Y.; Li, S. Spatiotemporal Patterns and Drivers of Land Use and Land Cover Change in the China-MongoliaRussia Economic Corridor. Pol. J. Environ. Stud. 2021, 30, 2527-2541. [CrossRef]

104. Naboureh, A.; Bian, J.; Lei, G.; Li, A. A review of land use/land cover change mapping in the China-Central Asia-West Asia economic corridor countries. Big Earth Data 2021, 5, 237-257. [CrossRef]

105. Lashari, A.H.; Li, W.; Hassan, M.; Nabi, G.; Mabey, P.T.; Islam, M.M.; Rashid, W.; Ujjan, S.A.; Memon, K.H. Biodiversity Governance and Management in Pakistan: A Way Forward Through the China-Pakistan Economic Corridor. Pol. J. Environ. Stud. 2021, 30, 1-8. [CrossRef]

106. Huang, M.-X.; Li, S.-Y. The analysis of the impact of the Belt and Road initiative on the green development of participating countries. Sci. Total Environ. 2020, 722, 137869. [CrossRef]

107. Lechner, A.M.; Chan, F.; Campos-Arceiz, A. Biodiversity conservation should be a core value of China's Belt and Road Initiative. Nat. Ecol. Evol. 2018, 2, 408-409. [CrossRef]

108. Rashid, W.; Shi, J.; Rahim, I.u.; Dong, S.; Sultan, H. Issues and Opportunities Associated with Trophy Hunting and Tourism in Khunjerab National Park, Northern Pakistan. Animals 2020, 10, 597. [CrossRef]

109. Hussain, S. The status of the snow leopard in Pakistan and its conflict with local farmers. Oryx 2003, 37, 26-33. [CrossRef]

110. Ali, A. A Siachen Peace Park: The Solution to a Half-Century of International Conflict? Mt. Res. Dev. 2002, 22, 316-319. [CrossRef]

111. Ali, S.; Xu, H.; Ahmed, W. Resolving strategic conflict for environmental conservation of glacial ecosystem: An attitudinal conflict resolution approach. Int. J. Glob. Warm. 2019, 18, 221-238. [CrossRef]

112. Davis, A.E.; Gamble, R.; Roche, G.; Gawne, L. International relations and the Himalaya: Connecting ecologies, cultures and geopolitics. Aust. J. Int. Aff. 2021, 75, 15-35. [CrossRef]

113. Gaynor, K.M.; Fiorella, K.J.; Gregory, G.H.; Kurz, D.J.; Seto, K.L.; Withey, L.S.; Brashares, J.S. War and wildlife: Linking armed conflict to conservation. Front. Ecol. Environ. 2016, 14, 533-542. [CrossRef]

114. Aeschbach-Hertig, W.; Gleeson, T. Regional strategies for the accelerating global problem of groundwater depletion. Nat. Geosci. 2012, 5, 853-861. [CrossRef]

115. Meadowcroft, J. Politics and scale: Some implications for environmental governance. Landsc. Urban Plan. 2002, 61, 169-179. [CrossRef]

116. Ritchie, E.G.; Elmhagen, B.; Glen, A.S.; Letnic, M.; Ludwig, G.; McDonald, R.A. Ecosystem restoration with teeth: What role for predators? Trends Ecol. Evol. 2012, 27, 265-271. [CrossRef] [PubMed]

117. Wilman, E.A.; Wilman, E.N. Modeling outcomes of approaches to sustained human and snow leopard coexistence. Conserv. Biol. 2015, 30, 50-58. [CrossRef]

118. Murali, R.; Redpath, S.; Mishra, C. The value of ecosystem services in the high altitude Spiti Valley, Indian Trans-Himalaya. Ecosyst. Serv. 2017, 28, 115-123. [CrossRef]

119. Namgail, T.; Majumder, B.; Dadul, J. Himalayan Homestays: Fostering Human-Snow Leopard Coexistence. In SNOW LEOPARDS, Biodiversity Of The World: Conservation From Genes To Landscapes; Academic Press: London, UK, 2016; pp. 164-168. [CrossRef]

120. Schutgens, M.G.; Hanson, J.H.; Baral, N.; Ale, S.B. Visitors' willingness to pay for snow leopard Panthera uncia conservation in the Annapurna Conservation Area, Nepal. Oryx 2018, 52, 1-10. [CrossRef]

121. Foggin, J.M. Depopulating the Tibetan Grasslands. Mt. Res. Dev. 2008, 28, 26-31. [CrossRef] 
122. Zakharenka, A.; Sharma, K.; Kochorov, C.; Rutherford, B.; Varma, K.; Seth, A.; Kushlin, A.; Lumpkin, S.; Seidensticker, J.; Laporte, B.; et al. The global snow leopard and ecosystem protection program. In SNOW LEOPARDS, Biodiversity of the World: Conservation from Genes to Landscapes; McCarthy, T., Mallon, D., Eds.; Academic Press: London, UK, 2016; pp. 559-573. [CrossRef]

123. Augugliaro, C.; Christe, P.; Janchivlamdan, C.; Baymanday, H.; Zimmermann, F. Patterns of human interaction with snow leopard and co-predators in the Mongolian western Altai: Current issues and perspectives. Glob. Ecol. Conserv. 2020, 24, e01378. [CrossRef]

124. Wen, L.; Dong, S.; Li, Y.; Li, X.; Shi, J.; Wang, Y.; Liu, D.; Ma, Y. Effect of Degradation Intensity on Grassland Ecosystem Services in the Alpine Region of Qinghai-Tibetan Plateau, China. PLoS ONE 2013, 8, e58432. [CrossRef] [PubMed]

125. Abhijitha, C.S.; Areendran, G.; Raj, K.; Bhat, P.; Sahana, M. Habitat linkages for Asian elephants in Central Indian landscape. In Habitat, Ecology and Ekistics. Advances in Asian Human-Environmental Research; Rukhsana, Haldar, A., Alam, A., Satpati, L., Eds.; Springer: Cham, Switzerland, 2021; pp. 75-89. [CrossRef]

126. Sanderson, E.W.; Mallon, D.; McCarthy, T.; Zahler, P.; Fisher, K. Global strategies for Snow Leopard conservation: A synthesis. In SNOW LEOPARDS, Biodiversity of the World: Conservation from Genes to Landscapes, 1st ed.; McCarthy, T., Mallon, D., Eds.; Academic Press: London, UK, 2016; pp. 543-558. [CrossRef]

127. Murali, R.; Lkhagvajav, P.; Saeed, U.; Kizi, V.A.; Jumabay-Uulu, K.; Nawaz, M.A.; Bhatnagar, Y.V.; Sharma, K.; Mishra, C. Valuation of Ecosystem Services in Snow Leopard Landscapes of Asia; Nature Conservation Foundation: Mysuru, India, 2017.

128. Atwood, T.B.; Valentine, S.A.; Hammill, E.; McCauley, D.J.; Madin, E.M.P.; Beard, K.H.; Pearse, W.D. Herbivores at the highest risk of extinction among mammals, birds, and reptiles. Sci. Adv. 2020, 2, 1-10. [CrossRef]

129. Young, H.S.; McCauley, D.J.; Galetti, M.; Dirzo, R. Patterns, Causes, and Consequences of Anthropocene Defaunation. Annu. Rev. Ecol. Evol. Syst. 2016, 47, 333-358. [CrossRef]

130. Hirt, M.R.; Barnes, A.D.; Gentile, A.; Pollock, L.J.; Rosenbaum, B.; Thuiller, W.; Tucker, M.A.; Brose, U. Environmental and anthropogenic constraints on animal space use drive extinction risk worldwide. Ecol. Lett. 2021, 24, 2576-2585. [CrossRef]

131. Kremen, C.; Merenlender, A.M. Landscapes that work for biodiversity and people. Science 2018, 362, 304. [CrossRef]

132. Johansson, Ö.; Rauset, G.R.; Samelius, G.; McCarthy, T.; Andrén, H.; Tumursukh, L.; Mishra, C. Land sharing is essential for snow leopard conservation. Biol. Conserv. 2016, 203, 1-7. [CrossRef]

133. Jackson, R. Fostering community-based stewardship of wildlife in Central Asia: Transforming Snow Leopards from pests into valued assets. In Rangeland Stewardship in Central Asia: Balancing Improved Livelihoods, Biodiversity Conservation and Land Protection; Squires, V., Ed.; SpringerLink: Dordrecht, The Netherlands, 2012. [CrossRef]

134. Foggin, J.M.; Lechner, A.M.; Emslie-Smith, M.; Hughes, A.C.; Sternberg, T.; Dossani, R. Belt and Road Initiative in Central Asia: Anticipating socioecological challenges from large-scale infrastructure in a global biodiversity hotspot. Conserv. Lett. 2021, 14, e12819. [CrossRef]

135. Hanson, J.H.; Schutgens, M.; Baral, N. What explains tourists' support for snow leopard conservation in the Annapurna Conservation Area, Nepal? Hum. Dimens. Wildl. 2019, 24, 31-45. [CrossRef]

136. Alexander, J.; Chen, P.; Damerell, P.; Youkui, W.; Hughes, J.; Shi, K.; Riordan, P. Human wildlife conflict involving large carnivores in Qilianshan, China and the minimal paw-print of snow leopards. Biol. Conserv. 2015, 187, 1-9. [CrossRef]

137. Bagchi, S.; Mishra, C. Living with large carnivores: Predation on livestock by the snow leopard (Uncia uncia). J. Zool. 2006, 268, 217-224. [CrossRef]

138. Ascensão, F.; D'Amico, M.; Barrientos, R. No Planet for Apes? Assessing Global Priority Areas and Species Affected by Linear Infrastructures. Int. J. Primatol. 2021. [CrossRef]

139. Sheikh, K.; Ahmad, T.; Khan, M.A. Use, exploitation and prospects for conservation: People and plant biodiversity of Naltar Valley, northwestern Karakorums, Pakistan. Biodivers. Conserv. 2002, 11, 715-742. [CrossRef]

140. Shrestha, B.; Kindlmann, P. Implications of landscape genetics and connectivity of snow leopard in the Nepalese Himalayas for its conservation. Sci. Rep. 2020, 10, 19853. [CrossRef] [PubMed]

141. Farhadinia, M.S.; Maheshwari, A.; Nawaz, M.A.; Ambarlı, H.; Gritsina, M.A.; Koshkin, M.A.; Rosen, T.; Hinsley, A.; Macdonald, D.W. Belt and Road Initiative may create new supplies for illegal wildlife trade in large carnivores. Nat. Ecol. Evol. 2019, 3, 1267-1268. [CrossRef] [PubMed]

142. Esmail, N.; Wintle, B.C.; Sas-Rolfes, M.T.; Athanas, A.; Beale, C.M.; Bending, Z.; Dai, R.; Fabinyi, M.; Gluszek, S.; Haenlein, C.; et al. Emerging illegal wildlife trade issues: A global horizon scan. Conserv. Lett. 2020, 13, e12715. [CrossRef]

143. Chong, K.L. The side effects of mass tourism: The voices of Bali islanders. Asia Pac. J. Tour. Res. 2019, 25, 157-169. [CrossRef]

144. Zorpas, A.A.; Voukkali, I.; Pedreño, J.N. Tourist area metabolism and its potential to change through a Proposed Strategic Plan in the framework of Sustainable Development. J. Clean. Prod. 2018, 172, 3609-3620. [CrossRef]

145. Akis, A. The effects of mass tourism: A case study from Manavgat (Antalya-Turkey). Procedia Soc. Behav. Sci. 2011, 19, 289-296. [CrossRef]

146. Rico, A.; Martínez-Blanco, J.; Montlleó, M.; Rodríguez, G.; Tavares, N.; Arias, A.; Oliver-Solà, J. Carbon footprint of tourism in Barcelona. Tour. Manag. 2019, 70, 491-504. [CrossRef]

147. Robinson, D.; Newman, S.P.; Stead, S.M. Community perceptions link environmental decline to reduced support for tourism development in small island states: A case study in the Turks and Caicos Islands. Mar. Policy 2019, 108, 103671. [CrossRef]

148. Fantinato, E. The impact of (mass) tourism on coastal dune pollination networks. Biol. Conserv. 2019, 236, 70-78. [CrossRef] 
149. Soboleva, E.; Krivokhizh, S. Chinese initiatives in Central Asia: Claim for regional leadership? Eurasian Geogr. Econ. 2021, 62, 634-658. [CrossRef]

150. Li, J.; Gao, J.; Li, W.; Zhang, Z.; Fu, J.; Shao, G.; Guo, X. An indicator framework for assessing cooperative cross-border conservation in the Karakoram-Himalayan region. Ecol. Indic. 2021, 126, 107658. [CrossRef]

151. Uddin, K.; Chettri, N.; Yang, Y.; Lodhi, M.S.; Htun, N.Z.; Sharma, E. Integrating geospatial tools and species for conservation planning in a data-poor region of the Far Eastern Himalayas. Geol. Ecol. Landsc. 2020, 4, 187-202. [CrossRef]

152. Yuan, J.-D. China's Role in Establishing and Building the Shanghai Cooperation Organization (SCO). J. Contemp. China 2010, 19, 855-869. [CrossRef]

153. Kembayev, Z. Implementing the Silk Road Economic Belt: From the Shanghai Cooperation Organisation to the Silk Road Union? Asia Eur. J. 2018, 16, 37-50. [CrossRef]

154. Ahmed, Z.S.; Ahmed, S.; Bhatnagar, S. Conflict or Cooperation? India and Pakistan in Shanghai Cooperation Organisation. Pac. Focus 2019, 34, 5-30. [CrossRef]

155. Garlick, J. The Regional Impacts of China's Belt and Road Initiative. J. Curr. Chin. Aff. 2020, 49, 3-13. [CrossRef]

156. Ali, S. The Siachen peace park proposal: Moving from concept to reality. Environment 2008, 50, 43.

157. Maheshwari, A. Ease conflict in Asia with snow leopard peace parks. Science 2020, 367, 1203. [CrossRef]

158. Freeman, O.E.; Duguma, L.A.; Minang, P.A. Operationalizing the integrated landscape approach in practice. Ecol. Soc. 2015, 20, 24-43. [CrossRef]

159. Takeuchi, K.; Ichikawa, K.; Elmqvist, T. Satoyama landscape as social-ecological system: Historical changes and future perspective. Curr. Opin. Environ. Sustain. 2016, 19, 30-39. [CrossRef]

160. Parrott, L.; Meyer, W.S. Future landscapes: Managing within complexity. Front. Ecol. Environ. 2012, 10, 382-389. [CrossRef]

161. Herrera-Franco, G.; Alvarado-Macancela, N.; Quinchuela, T.G.; Carrión-Mero, P. Participatory socio-ecological system: ManglaraltoSanta Elena, Ecuador. Geol. Ecol. Landsc. 2018, 2, 1-8. [CrossRef]

162. Foley, J.A.; Ramankutty, N.; Brauman, K.A.; Cassidy, E.S.; Gerber, J.S.; Johnston, M.; Mueller, N.D.; O'Connell, C.; Ray, D.K.; West, P.C.; et al. Solutions for a cultivated planet. Nature 2011, 478, 337-342. [CrossRef]

163. Reed, J.; Vianen, J.V.; Deakin, E.L.; Barlow, J.; Sunderland, T. Integrated landscape approaches to managing social and environmental issues in the tropics: Learning from the past to guide the future. Glob. Chang. Biol. 2016, 22, 2540-2554. [CrossRef]

164. Tscharntke, T.; Tylianakis, J.M.; Rand, T.A.; Didham, R.K.; Fahrig, L.; Batary, P.; Bengtsson, J.; Clough, Y.; Crist, T.O.; Dormann, C.F.; et al. Landscape moderation of biodiversity patterns and processes-Eight hypotheses. Biol. Rev. 2012, 87, 661-685. [CrossRef]

165. Weisshuhn, P. Indexing the vulnerability of biotopes to landscape changes. Ecol. Indic. 2019, 102, 316-327. [CrossRef]

166. Sayer, J.; Sunderland, T.; Ghazoul, J.; Pfund, J.-L.; Sheil, D.; Meijaard, E.; Venter, M.; Boedhihartono, A.K.; Day, M.; Garcia, C.; et al. Ten principles for a landscape approach to reconciling agriculture, conservation, and other competing land uses. Proc. Natl. Acad. Sci. USA 2012, 110, 8349-8356. [CrossRef]

167. Johansson, Ö.; McCarthy, T.; Samelius, G.; Andrén, H.; Tumursukh, L.; Mishra, C. Snow leopard predation in a livestock dominated landscape in Mongolia. Biol. Conserv. 2015, 184, 251-258. [CrossRef]

168. Jackson, R.; Wangchuk, R. Linking Snow Leopard Conservation and People-Wildlife Conflict Resolution:: Grassroots Measures to Protect the Endangered Snow Leopard from Herder Retribution. Endanger. Species Update 2001, 18, $138-141$.

169. Alexander, J.S.; Agvaantseren, B.; Gongor, E.; Mijiddorj, T.N.; Piaopiao, T.; Redpath, S.; Young, J.; Mishra, C. Assessing the Effectiveness of a Community-based Livestock Insurance Program. Environ. Manag. 2021, 68, 87-99. [CrossRef] [PubMed]

170. Crist, E.; Mora, C.; Engelman, R. The interaction of human population, food production, and biodiversity protection. Science 2017, 356, 260-264. [CrossRef] [PubMed]

171. Kumar, S.; Smith, S.R.; Fowler, G.; Velis, C.; Kumar, S.J.; Arya, S.; Rena; Kumar, R.; Cheeseman, C. Challenges and opportunities associated with waste management in India. R. Soc. Open Sci. 2017, 4, 1-11. [CrossRef]

172. Bradshaw, C.J.A.; Ehrlich, P.R.; Beattie, A.; Ceballos, G.; Crist, E.; Diamond, J.; Dirzo, R.; Ehrlich, A.H.; Harte, J.; Harte, M.E.; et al. Underestimating the Challenges of Avoiding a Ghastly Future. Front. Conserv. Sci. 2021, 1, 9. [CrossRef]

173. Huang, L.; Shao, Q.; Liu, J.; Lu, Q. Improving ecological conservation and restoration through payment for ecosystem services in Northeastern Tibetan Plateau, China. Ecosyst. Serv. 2018, 31, 181-193. [CrossRef]

174. Arriagada, R.; Villaseñor, A.; Rubiano, E.; Cotacachi, D.; Morrison, J. Analysing the impacts of PES programmes beyond economic rationale: Perceptions of ecosystem services provision associated to the Mexican case. Ecosyst. Serv. 2018, 29, 116-127. [CrossRef]

175. Kaczan, D.; Pfaff, A.; Rodriguez, L.; Shapiro-Garza, E. Increasing the impact of collective incentives in payments for ecosystem services. J. Environ. Econ. Manag. 2017, 86, 48-67. [CrossRef]

176. Waylen, K.A.; Martin-Ortega, J. Surveying views on Payments for Ecosystem Services: Implications for environmental management and research. Ecosyst. Serv. 2018, 29, 23-30. [CrossRef]

177. Liu, Y.; Zhang, R.; Zhao, W.; Wang, S.; Fu, B. Comparison between tourists' and inhabitants' willingness to pay for nature in the Tibetan Plateau. J. Clean. Prod. 2020, 255, 120219. [CrossRef]

178. Badola, R.; Ahmed, T.; Gill, A.K.; Dobriyal, P.; Das, G.C.; Badola, S.; Hussain, S.A. An incentive-based mitigation strategy to encourage coexistence of large mammals and humans along the foothills of Indian Western Himalayas. Sci. Rep. 2021, 11, 1-13. [CrossRef] [PubMed]

179. Bai, X.; Huang, Y.; Ren, W.; Coyne, M.; Jacinthe, P.A.; Tao, B.; Hui, D.; Yang, J.; Matocha, C. Responses of soil carbon sequestration to climate-smart agriculture practices: A meta-analysis. Glob. Chang. Biol. 2019, 25, 2591-2606. [CrossRef] 
180. Khatri-Chhetri, A.; Pant, A.; Aggarwal, P.K.; Vasireddy, V.V.; Yadav, A. Stakeholders prioritization of climate-smart agriculture interventions: Evaluation of a framework. Agr. Syst. 2019, 174, 23-31. [CrossRef]

181. Chhogyel, N.; Kumar, L.; Bajgai, Y. Consequences of Climate Change Impacts and Incidences of Extreme Weather Events in Relation to Crop Production in Bhutan. Sustainability 2020, 12, 4319. [CrossRef]

182. Mazhar, R.; Ghafoor, A.; Xuehao, B.; Wei, Z. Fostering sustainable agriculture: Do institutional factors impact the adoption of multiple climate-smart agricultural practices among new entry organic farmers in Pakistan? J. Clean. Prod. 2021, 283, 124620. [CrossRef]

183. Subedi, R.; Bhatta, L.D.; Udas, E.; Agrawal, N.K.; Joshi, K.D.; Panday, D. Climate-smart practices for improvement of crop yields in mid-hills of Nepal. Cogent Food Agric. 2019, 5, 1631026. [CrossRef]

184. Ross, S.R.P.-J.; Molinos, J.G.; Okuda, A.; Johnstone, J.; Atsumi, K.; Futamura, R.; Williams, M.A.; Matsuoka, Y.; Uchida, J.; Kumikawa, S.; et al. Predators mitigate the destabilising effects of heatwaves on multitrophic stream communities. Glob. Chang. Biol. 2022, 28, 403-416. [CrossRef]

185. Sala, E. Top predators provide insurance against climate change. Trends Ecol. Evol. 2006, 21, 479-480. [CrossRef]

186. Snow Leopard Trust. Transboundary Cooperation for Snow Leopard and Ecosystem Conservation; Global Snow Leopard and Ecosystem Protection Programme: Bishkek, Kyrgyzstan, 2021; pp. 1-70.

187. Bawa, K.S.; Koh, L.P.; Lee, T.M.; Liu, J.; Ramakrishnan, P.S.; Yu, D.W.; Zhang, Y.-p.; Raven, P.H. China, India, and the Environment. Science 2010, 327, 1457-1459. [CrossRef]

188. Liu, Y.; Hao, Y. The dynamic links between $\mathrm{CO}_{2}$ emissions, energy consumption and economic development in the countries along "the Belt and Road". Sci. Total Environ. 2018, 645, 674-683. [CrossRef] [PubMed]

189. Wu, H.; Ren, S.; Yan, G.; Hao, Y. Does China's outward direct investment improve green total factor productivity in the "Belt and Road" countries? Evidence from dynamic threshold panel model analysis. J. Environ. Manag. 2020, 275, 111295. [CrossRef] [PubMed]

190. Cuiyun, C.; Chazhong, G. Green development assessment for countries along the belt and road. J. Environ. Manag. 2020, 263, 110344. [CrossRef] [PubMed]

191. Brooks, T.M.; Akçakaya, H.R.; Burgess, N.D.; Butchart, S.H.M.; Hilton-Taylor, C.; Hoffmann, M.; Juffe-Bignoli, D.; Kingston, N.; MacSharry, B.; Parr, M.; et al. Analysing biodiversity and conservation knowledge products to support regional environmental assessments. Sci. Data 2016, 3, 160007. [CrossRef] [PubMed]

192. Cheshmehzangi, A.; Xie, L.; Tan-Mullins, M. Pioneering a Green Belt and Road Initiative (BRI) alignment between China and other members: Mapping BRI's sustainability plan. Blue-Green Syst. 2021, 3, 49-61. [CrossRef]

193. Dickman, A.; Packer, C.; Johnson, P.J.; Macdonald, D.W. A sideways look at conservation and consistency in tourism policy. Conserv. Biol. 2018, 32, 744-746. [CrossRef]

194. Cristiano, S.d.C.; Rockett, G.C.; Portz, L.C.; Filho, J.R.d.S. Beach landscape management as a sustainable tourism resource in Fernando de Noronha Island (Brazil). Mar. Pollut. Bull. 2020, 150, 110621. [CrossRef]

195. Macdonald, C.; Gallagher, A.J.; Barnett, A.; Brunnschweiler, J.; Shiffman, D.S.; Hammerschlag, N. Conservation potential of apex predator tourism. Biol. Conserv. 2017, 215, 132-141. [CrossRef]

196. Vannelli, K.; Hampton, M.P.; Namgail, T.; Black, S.A. Community participation in ecotourism and its effect on local perceptions of snow leopard (Panthera uncia) conservation. Hum. Dimens. Wildl. 2019, 24, 180-193. [CrossRef]

197. Pătru-Stupariu, I.; Hossu, C.A.; Grădinaru, S.R.; Nita, A.; Stupariu, M.-S.; Huzui-Stoiculescu, A.; Gavrilidis, A.-A. A Review of Changes in Mountain Land Use and Ecosystem Services: From Theory to Practice. Land 2020, 9, 336. [CrossRef]

198. Pătru-Stupariu, I.; Nita, A.; Mustățea, M.; Huzui-Stoiculescu, A.; Fürst, C. Using social network methodological approach to better understand human-wildlife interactions. Land Use Policy 2020, 99, 105009. [CrossRef]

199. Popescu, V.D.; Pop, M.I.; Rozylowicz, L. Trophy hunting undermines public trust. Science 2021, 372, 1049. [CrossRef] [PubMed] 